\title{
Exercise-Induced Plasticity in Signaling Pathways Involved in Motor Recovery after Spinal Cord Injury
}

\author{
Jadwiga N. Bilchak, Guillaume Caron (D) and Marie-Pascale Côté *(D) \\ Marion Murray Spinal Cord Research Center, Department of Neurobiology and Anatomy, Drexel University, \\ Philadelphia, PA 19129, USA; jnb94@drexel.edu (J.N.B.); guillaume.caron@u-paris.fr (G.C.) \\ * Correspondence: mc849@drexel.edu; Tel.: +1-215-991-8598
}

Citation: Bilchak, J.N.; Caron, G.; Côté, M.-P. Exercise-Induced Plasticity in Signaling Pathways Involved in Motor Recovery after Spinal Cord Injury. Int. J. Mol. Sci. 2021, 22, 4858. https://doi.org/ $10.3390 /$ ijms22094858

Academic Editor: Nolan Hoffman

Received: 14 April 2021

Accepted: 29 April 2021

Published: 4 May 2021

Publisher's Note: MDPI stays neutral with regard to jurisdictional claims in published maps and institutional affiliations.

Copyright: (c) 2021 by the authors. Licensee MDPI, Basel, Switzerland This article is an open access article distributed under the terms and conditions of the Creative Commons Attribution (CC BY) license (https:// creativecommons.org/licenses/by/ $4.0 /)$

\begin{abstract}
Spinal cord injury (SCI) leads to numerous chronic and debilitating functional deficits that greatly affect quality of life. While many pharmacological interventions have been explored, the current unsurpassed therapy for most SCI sequalae is exercise. Exercise has an expansive influence on peripheral health and function, and by activating the relevant neural pathways, exercise also ameliorates numerous disorders of the central nervous system (CNS). While the exact mechanisms by which this occurs are still being delineated, major strides have been made in the past decade to understand the molecular underpinnings of this essential treatment. Exercise rapidly and prominently affects dendritic sprouting, synaptic connections, neurotransmitter production and regulation, and ionic homeostasis, with recent literature implicating an exercise-induced increase in neurotrophins as the cornerstone that binds many of these effects together. The field encompasses vast complexity, and as the data accumulate, disentangling these molecular pathways and how they interact will facilitate the optimization of intervention strategies and improve quality of life for individuals affected by SCI. This review describes the known molecular effects of exercise and how they alter the CNS to pacify the injury environment, increase neuronal survival and regeneration, restore normal neural excitability, create new functional circuits, and ultimately improve motor function following SCI.
\end{abstract}

Keywords: exercise; rehabilitation; spinal cord injury; sprouting; regeneration; BDNF; serotonin; chloride homeostasis; KCC2

\section{Introduction}

Spinal cord injury (SCI) is a devastating condition and a major cause of disability, with up to half a million cases reported every year worldwide [1]. In the United States alone, there are an estimated 300,000 people living with a spinal cord injury (SCI), with approximately 17,000 new cases arising each year [1]. SCI is associated with substantial personal and societal costs, as well as secondary complications that often exceed the original injury and lead to a reduced quality of life and increased rates of mortality. While there is yet no definitive cure for SCI, many of its sequalae can be alleviated by exercise-based rehabilitation programs and activity-based therapies. In the clinic, the planned, structured, and repetitive physical activity produced by spinal networks and skeletal muscle has noticeable beneficial effects on an array of functional systems, including respiratory [2-4], cardiovascular [5,6] bladder, bowel, and sexual function [7,8]. In addition, by providing repetitive and relevant sensory cues, effective rehabilitation strategies have the potential to retrain the nervous system to improve performance of motor tasks such as walking and standing [9-13].

Rehabilitation approaches that promote repetitive motor activity are considered the gold-standard therapy and are widely used in the clinic as a critical component of successful functional recovery in SCI individuals $[9,14,15]$. The beneficial effects of exercise after SCI suggest that it provides sufficient excitation to the nervous system to promote the activity both of uninjured spinal pathways and of residual supraspinal inputs. While clinical studies are necessary to test whether specific strategies provide relief for individuals with SCI, 
these rely on evidence-based therapies $[6,16]$, which do little to elucidate the mechanisms contributing to recovery [15]. Therefore, investigating activity-dependent plasticity in animal models is critical, not only to optimize rehabilitation programs in the clinic, but also to identify potential pharmacological strategies. These may be used either in place of exercise when it is not possible due to comorbidities or lack of access, or in conjunction with exercise to enhance functional improvements. It is thus imperative that the molecular underpinnings of exercise are understood in full in order to maximize its potential in the clinic.

There is abundant evidence that exercise facilitates motor recovery after SCI, but how an increase in physical activity leads to improvements in neurological function, especially in terms of molecular mechanisms that promote plasticity of the injured spinal cord, remains elusive. In this review, we compile and summarize how exercise affects signaling pathways in the spinal cord to enhance functional motor recovery after SCI. Together, the current literature suggests that exercise can: (1) modify the injury environment; (2) promote axonal sprouting of local spinal networks and remaining descending axons; (3) promote synaptic and ionic plasticity; and, importantly, (4) improve motor functions in both the hindlimbs and forelimbs, validating the therapeutic potential of task-specific rehabilitation for functional recovery after chronic SCI.

\section{Effect of Rehabilitation on Spinal Networks below the Injury}

\subsection{Synaptic Plasticity and Synapse Formation}

Synaptic plasticity plays a pivotal role in functional recovery after SCI, and extensive molecular and morphological changes have been documented that implicate exercise as a reliable initiator of activity-dependent neuroplasticity. After a thoracic SCI, exercise causes lumbar spinal neurons below the injury to display an increase in: (1) the expression of synaptophysin $[17,18]$ and Synapsin I [19], important presynaptic markers; (2) the expression of PSD-95 [17], a postsynaptic scaffolding protein; and (3) the number of VGlut $1^{+}$terminals, an indicator of glutamatergic synapses [20]. Together, these changes indicate an increased number of synaptic inputs below the lesion [21] (Figure 1A). While the relationship between the density of synaptic inputs and their efficiency cannot be determined based on anatomical data alone, these changes observed in the lumbar cord are associated with an improvement in stepping performance. Similarly, reaching and grasping training significantly increases Synapsin I around ventral horn motoneurons in the cervical spinal cord caudal to the lesion and is associated with improved reaching and grasping ability [22]. Overall, this suggests that by providing repeated activity within neural networks, exercise strengthens synaptic connections and either promotes synaptic formation and/or maintains synapses that would have otherwise degraded after injury. The neuronal populations from which these synaptic structures originate is uncertain, but their presence after a complete spinal cord transection suggests that this synaptic reorganization may originate from sensory afferents as well as a number of interneurons. Models of incomplete injuries also suggest a role for sprouting of spared supraspinal pathways (further discussed in Section 3).

There are several mechanisms by which exercise likely promotes synaptic plasticity. For example, exercise increases synthesis of the transcription factor cyclic AMP response element binding protein (CREB) and its phosphorylated form, pCREB, in the spinal cord caudal to the injury, in association with improved functional recovery $[19,23]$ (Figure 1B). CREB is one of the best-characterized transcription factors and contributes to cell survival following insults to the CNS, as well as motor learning [24,25]. Another possible contributing factor is that exercise prevents the SCI-induced downregulation of perineuronal nets (PNNs) around lumbar motoneurons below the lesion site [20,26,27]. PNNs are formed of extracellular matrix molecules, i.e., chondroitin sulphate proteoglycans (CSPGs) that aggregate extracellularly on the surface of neuronal cell bodies and proximal dendrites [28]. The role of PNNs is complex and can be both protective and inhibitory; while they restrict axonal plasticity and limit the ability of the spinal cord to reorganize following injury, they 
are also involved in the fine-tuning of function by regulating ion buffering, neuroprotection, and synaptic stabilization, and by curtailing aberrant plasticity [29]. There is also strong evidence that PNNs are associated with activity-dependent synaptic plasticity during development [30] and after injury [31]. Although the effect of rehabilitation on PNNs remains to be fully described, recent studies have suggested that rehabilitation increases PNNs and the level of CSPGs in the lumbar spinal cord in intact animals [26] and in animals with SCI [27], in association with improved functional recovery. This suggests that the increased neuronal activity provided by exercise may prevent the loss of stabilizing structures and maintain existing synapses through an increase in expression of CSPGs and PNNs in the associated spinal circuits. There is also substantial evidence supporting an exercise-induced formation of new synapses. Exercise increases the growth-associated Protein 43 (GAP43) after SCI [19], which appears to act in concert with Synapsin I [32]. GAP43 is expressed at high levels in neuronal growth cones (Figure 1C), and plays a critical role in axon growth, regeneration, and the formation of new connections [33]. Additionally, large changes in morphology have been reported, implying that new circuits are formed.

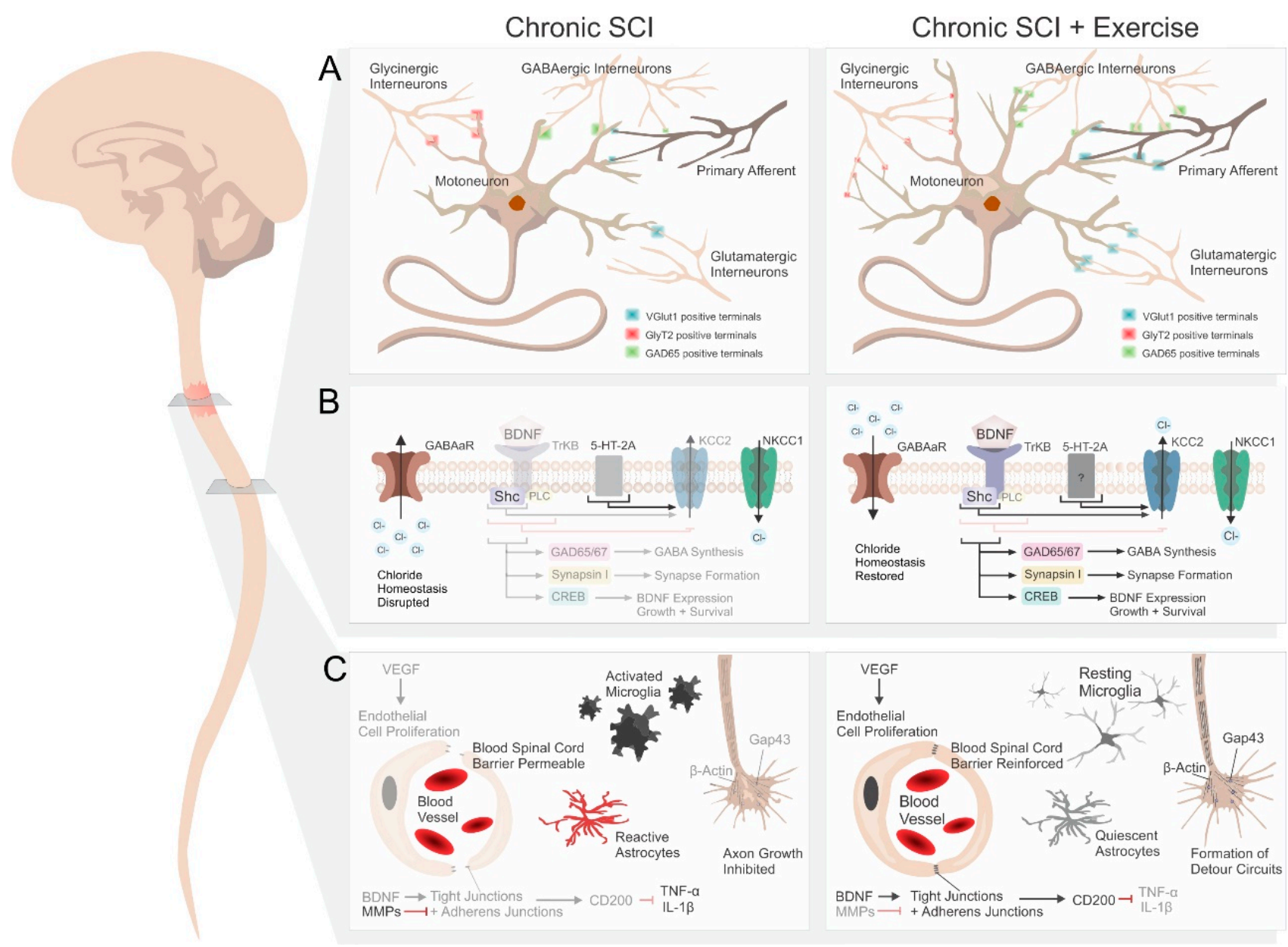

Figure 1. Schematic representation of various alterations induced by exercise following spinal cord injury (SCI). (A) Below the lesion, SCI causes atrophy of motoneuronal dendrites, reduced number of motoneuronal synapses, and less pre-synaptic inhibition of primary afferents. Exercise increases/maintains the number of synapses on motoneurons, as well as on primary afferents, with various changes in synaptic terminal size. (B) Many signaling pathways that ensue following SCI and exercise depend on BDNF signaling, including chloride homeostasis, neurotransmitter regulation, synapse formation, and neuronal growth and survival. The $5-\mathrm{HT} 2{ }_{\mathrm{A}} \mathrm{R}$ is believed to be upregulated after $\mathrm{SCI}$, and further enhanced by exercise. (C) Within and around the lesion site, exercise increases angiogenesis, axon sprouting, and detour circuit formation, while reducing inflammation and glia reactivity. 
SCI causes significant dendritic atrophy and synaptic stripping of motoneurons caudal to the lesion [18,34], and both treadmill training [18] and bike-training [35] were shown to increase dendritic density and total neurite length compared to sedentary controls. Upon closer examination, it was found that the size, density, and total number of various synapses on lumbar motoneurons of exercised animals with SCI differed substantially from those in intact animals [36]. This was accompanied by significant recovery of locomotor ability. This suggests, perhaps not surprisingly, that recovery after a major insult to the CNS is not necessarily a restoration of pre-injury properties, but a functional adaptation to a "new normal" [37].

\subsection{Neurotrophins}

Neurotrophins, such as brain-derived neurotrophic factor (BDNF), glial-cell-derived neurotrophic factor (GDNF), and Neurotrophins 3 and 4 (NT-3 and NT-4, respectively), are a class of growth factors that promote neurogenesis, neuroregulation, synaptic regeneration, neuroprotection, and neuronal survival [38-40]. BDNF and its high affinity receptor, TrkB, often dominate the spotlight, as countless studies have identified them as key players in many SCI sequelae, as well as in the pathways associated with exercise-based recovery (Figure 1B).

BDNF was shown to be regulated in a neural activity-dependent manner [41], and it has been known since the 1990s that physical activity in general, and the resultant neuronal activity, enhances the expression of BDNF in the CNS in animal models [42]. While some molecular markers of plasticity are modulated in a task-dependent manner [43], BDNF is increased whether the rehabilitation program incorporates conventional treadmill training [18,44-46], water treadmill training [47], passive bicycling [44], wheel running [19], or swimming [45], regardless of sex and severity of injury. In humans, the results have become equally convincing, with even short bouts of exercise increasing BDNF serum levels in non-injured individuals and individuals with SCI alike [48-50].

SCI induces an abrupt decrease in activity of neural networks, which leads to reduced BDNF in the lumbar spinal cord below the injury $[19,23,45,51,52]$ (Table 1). By repetitively activating the relevant neural networks, exercise promotes BDNF mRNA and protein expression in muscles [53] and throughout the length of the spinal cord [18,19,23,44,45,47,51,52,54]. This increase in BDNF promotes plasticity, bolsters the effect of descending drive on motoneurons, and helps normalize motoneuronal properties $[21,55,56]$. Consequently, the exerciseassociated increase in BDNF is accompanied by multiple forms of functional recovery, including improved locomotor performance and decreased spasticity and allodynia $[23,44,46,56]$. The variety of sensorimotor functional improvements associated with the activity-dependent increase in BDNF after SCI likely stems from the complex and widespread influence that BDNF has on numerous biological functions, including axon regeneration, synaptic plasticity, myelination, neuronal survival, and reduced inflammation (reviewed in [56,57]), and its complex interplay with different neurotransmitter cascades [58]. This versatility is perhaps due to the diverse molecular reach of BDNF's high-affinity receptor, TrkB. Once BDNF binds to the TrkB receptor, three major intracellular signaling cascades ensue: the PI3-K/Akt pathway, the PLC/PKC pathway, and the Ras/ERK pathway, all of which modulate neuronal survival, growth, and plasticity to varying degrees with exercise following SCI. This can be inferred by BDNF-associated increases in synaptic markers [18,19], inhibitory neurotransmitters [23], and transcription factors $[19,23,47]$ (Figure 1B).

The BDNF/TrkB pathway is known to increase both synthesis and phosphorylation of Synapsin I to trigger the MAPK signaling pathway and modulate neurotransmitter release in cortical neurons [59]. It is believed that the exercise-induced increase in BDNF may account for the observed increase in Synapsin I phosphorylation in SCI rats [19], as previously reported in the hippocampus [60]. While many experiments have highlighted a correlation between increases in BDNF and exercise-based recovery, a growing number of studies have confirmed its necessary and causal role in the recovery processes. When TrkB-IgG, a molecule that competes with endogenous TrkB and thus sequesters BDNF, 
is delivered to animals undergoing rehabilitation, the exercise-induced improvements in allodynia [46], locomotor impairment [61], and spasticity [62] are eliminated. The activitydependent increase in BDNF/TrkB is also associated with an increase in synthesis of the transcription factor cyclic AMP response element binding protein (CREB) and p-CREB, its phosphorylated form, in the spinal cord caudal to the lesion [19,23]. Accordingly, blocking TrkB signaling after SCI significantly reduces CREB and p-CREB and prevents activitydependent functional recovery [23,47]. Together, these studies unequivocally identify BDNF-TrkB as a crucial agent of exercise-mediated signaling.

In the hippocampus [63], prolonged exercise was found to induce an accumulation of the metabolite $\beta$-hydroxybutyrate (BHB) in the liver. BHB crosses the blood-brain barrier into hippocampal neurons, in which it inhibits the class I histone deacetylases HDAC2 and HDAC3, which act upon selective BDNF promoters. In doing so, BHB specifically promotes BDNF expression via $\mathrm{Ca}^{2+}$-dependent epigenetic modifications [64-66]. While it is plausible that a similar mechanism exists in the spinal cord, and a class I HDAC inhibitor was recently shown to induce modest locomotor improvements in SCI mice [67], a direct link between exercise-induced metabolites and BDNF has yet to be demonstrated in an SCI model.

While BDNF signaling responds to exercise most prominently, other neurotrophins, such as NT-3 [19,44,45,52,68], NT-4 [44,69], NGF, and GDNF [44,53], are also linked with exercise-induced recovery after SCI. However, these growth factors are less frequently studied following SCI, and their contribution to recovery remains incompletely understood. Nonetheless, there is overwhelming evidence suggesting that exercise increases the expression of various neurotrophins after SCI, and that it contributes to facilitate recovery. This is further supported by experiments in which exogenous neurotrophins are provided and contribute to functional recovery $[57,70-73]$. However, increasing neurotrophins, particularly BDNF, after SCI is not likely the perfect remedy for SCI patients. Exogenous delivery of BDNF can be accompanied by debilitating side effects, such as neuropathic pain and hyperreflexia $[57,72,74-76]$. While the intensity, duration, and type of exercise yields differential increases of BDNF in the spinal cord of animals with SCI $[19,45,77,78]$ and in blood serum in humans [50], it appears that exercise does not produce BDNF in detrimental excess. This suggests that exercise has a homeostatic effect, and to date, exercise is considered the safest method of increasing neurotrophin expression.

\subsection{Serotonin Receptors}

Serotonin (5-HT) is a vital neurotransmitter in the mammalian spinal cord, playing an essential role in modulating sensorimotor function. In the intact spinal cord, serotoninergic innervation is almost entirely derived from the raphe nuclei in the brainstem, which is lost $[79,80]$ or severely compromised following SCI [81]. The drastic and sudden decrease in serotonin availability below the lesion renders spinal networks unexcitable and unresponsive [82,83], which critically contributes to SCI-induced paralysis [80]. The importance of 5-HT to movement is exemplified by the restoration of neuronal excitability and associated locomotor behaviors observed when 5-HT or 5-HT receptor agonists are administered, both in the acute or chronic phase of injury (reviewed in [84]). However, while spinal 5-HT availability is undeniably decreased after SCI, the serotonergic system remains challenging to study compared to other systems, as it comprises intraspinal and supraspinal neurons, as well as numerous receptors, all of which are highly plastic.

The serotoninergic system exerts its function via an interaction between 5-HT and a number of 5-HT receptors expressed in the spinal cord. Following SCI, the loss of descending 5-HT supply causes 5-HT receptors to undergo varying degrees of plasticity, depending on the specific subtype. Here, we will mainly focus on the receptors that have been clearly demonstrated to undergo anatomical and/or functional changes following injury and impact motor output.

Considerable interest has been devoted to $5-\mathrm{HT}_{1 \mathrm{~A}}, 5-\mathrm{HT}_{2 \mathrm{~A}}$, and $5-\mathrm{HT}_{2 \mathrm{C}}$ in terms of their anatomical and functional changes, likely due to their direct involvement in 
regulating motoneuronal excitability and functional recovery after SCI $[80,85]$. In the chronic phase of SCI, a number of 5-HT receptors are upregulated in the spinal cord. Most notably 5- $\mathrm{HT}_{1 \mathrm{~A}}[35,86], 5-\mathrm{HT}_{2 \mathrm{~A}}[35,87-92]$, and 5- $\mathrm{HT}_{2 \mathrm{C}}[79,81,93]$ (Table 1). This increase in receptor expression perhaps represents the development of a compensatory mechanism to counterbalance the lack of 5-HT. This is supported by the fact that (1) motoneurons become extremely sensitive even to small amounts of 5-HT [82]; (2) pharmacologically activating 5 -HT receptors after $\mathrm{SCI}$ with quipazine $\left(5-\mathrm{HT}_{2 \mathrm{~A} / 2 \mathrm{C}} \mathrm{R}\right.$ agonist) and 8 -OH-DPAT $\left(5-\mathrm{HT}_{1 \mathrm{~A} / 7} \mathrm{R}\right.$ agonist) can prevent the upregulation of $5-\mathrm{HT}_{1 \mathrm{~A} / 2 \mathrm{~A}}$ receptors below the lesion [35]; and (3) $5-\mathrm{HT}_{2 \mathrm{C}} \mathrm{R}$ becomes constitutively active (active in the absence of 5-HT) after chronic $\mathrm{SCI}$ in rat motoneurons, which contributes to the recovery of locomotion $[79,94]$. Interestingly, while 5-HT1A/2A/2C R are increased after injury, exercise does not decrease their expression toward intact levels $[35,87]$ to restore motor function as it does for inhibitory markers (see Section 2.4) and BDNF (Section 2.2). This is likely because 5-HT is not produced in the spinal cord. Instead, exercise further enhances the expression of $5-\mathrm{HT}_{2 \mathrm{~A}} \mathrm{R}$ (Figure $1 \mathrm{~B}$ ), a change that is specifically observed in extensor motoneurons [87].

These studies have led to the use of Buspirone, a $5-\mathrm{HT}_{1 \mathrm{~A} / 2 / 7} \mathrm{R}$ agonist, in human subjects with SCI to enhance spinal cord excitability and promote locomotor recovery, either alone or in combination with activity-based interventions such as treadmill training [95-97] or other pharmacological agents [98]. Interestingly, the presence of sensory feedback from the limbs is critical to the upregulation of $5-\mathrm{HT}_{1 \mathrm{~A}} \mathrm{R}$, as it does not occur in deafferented animals after SCI [86]. Since the presence of proprioceptive feedback is essential to motor recovery [99], this further supports a role for limb afferents to enhance 5-HT receptor expression in response to exercise. In addition, while exercise does not prevent $5{ }_{-\mathrm{HT} 1 / 2} \mathrm{R}$ upregulation, combining passive bicycling with 5-HT agonists both prevented the upregulation and improved locomotor recovery [35]. This is in agreement with other studies demonstrating that although 5-HT agonists improve functional recovery, the approach is more successful when combined with exercise $[36,100,101]$, suggesting a synergistic effect. However, the potential to translate this to the clinic remains unclear, as 5-HT agonists also trigger undesirable effects and contribute to psychiatric disorders [102] and pain [103].

A lot remains to be determined about the intricacies of how exercise affects the different facets of serotoninergic pathways after $\mathrm{SCI}$, as the effect of exercise has not been investigated in regard to many 5-HT receptor subtypes. However, our current knowledge suggests that they have an important role in promoting activity-dependent neural plasticity.

\subsection{Inhibitory Neurotransmitters}

GABA and glycine are the chief inhibitory neurotransmitters in the central nervous system, making their synthesis and release important determinants of neuronal processing. Disruptions in GABAergic and glycinergic signaling have widespread functional effects, which range from schizophrenia to depression, epilepsy, and neuropathic pain [104,105]. After SCI, the loss of supraspinal descending input also results in alterations in inhibitory synaptic transmission. A number of factors contribute to this, including increases in (1) the size and density of presynaptic inhibitory inputs; (2) postsynaptic expression of glycinergic $(\mathrm{GlyR})$ and $\mathrm{GABA}_{\mathrm{A}}$ receptors $\left(\mathrm{GABA}_{\mathrm{A}} \mathrm{R}\right) ;(3)$ expression of the anchoring protein gephyrin, a peptide closely associated with GlyR; and (4) the two GABA synthetizing enzymes, glutamic acid decarboxylase 65 and $67\left(\mathrm{GAD}_{65}\right.$ and $\mathrm{GAD}_{67}$, respectively) in the spinal segments below the lesion [37,106-109].

Exercise has been shown to reverse/prevent the disruptions in GABAergic and glycinergic signaling in several pathologies, including epilepsy [110], neuropathic pain [111,112], anxiety [113], and also SCI. Specifically, step-training was shown to decrease $G_{A D}$, GlyR, and $\mathrm{GABA}_{\mathrm{A}} \mathrm{R}$ expression in the lumbar spinal cord toward intact levels after injury $[37,43,107]$ (Table 1). Interestingly, stand-training did not decrease the same markers of inhibition, hinting at the importance of providing appropriate proprioceptive feedback to restore spinal inhibition. While this reflects general changes in inhibitory signaling that arise after SCI, recent studies have suggested that plasticity in this pathway is more com- 
plex than initially thought. For example, a month following a contusive SCI, the expression of both $\mathrm{GAD}_{65}$ and $\mathrm{GAD}_{67}$ was reported to be decreased in the dorsal horn, rather than increased, with treadmill training reversing this effect, likely via BDNF-TrkB dependent pathways [23] (Figure 1B). Multiple factors may contribute to the discrepancies between studies, including the animal model, injury type/severity, and time after injury, but also the differences in where and how $\mathrm{GAD}_{67 / 65}$ was quantified. This is supported by a recent study in which $\mathrm{GAD}_{65}$ expression was increased in axon terminals on motoneuron somata, but decreased in presynaptic boutons contacting primary afferents [36,114]. By taking into account not only the overall expression of inhibitory markers, but also their density, size, and location, exercise was revealed to increase both the density and size of $\mathrm{GAD}_{65}$-positive presynaptic boutons (Figure 1A), suggesting an increase in modulation of afferent input, which perhaps contributes to the restoration of presynaptic inhibition [115]. In contrast, $\mathrm{GAD}_{65}$-positive axon terminals contacting motoneuron somata increased in number with exercise but shrank in size. Similarly, exercised animals displayed an increased number of glycinergic terminals contacting motoneuron somata, each of smaller size than those found in animals with SCI (Figure 1A). This suggests either sprouting of existing axon terminals, or newly formed connections from new/spared GABAergic and glycinergic interneurons. Interestingly, these exercise-induced changes were accompanied by significant recovery of locomotor ability, but differed substantially from the connections observed in intact animals. In fact, this was exemplified by the emergence of a new stepping pattern observed only in SCI-exercised rats [36]. This demonstrates that recovery does not necessarily involve a restoration of pre-injury properties, but a functional adaptation to new conditions [37].

While separate studies may have indicated opposite effects of injury on $\mathrm{GAD}_{67 / 65}$ expression, exercise was shown to counteract the changes, suggesting that exercise may have a homeostatic effect. This may occur via changes in BDNF-TrkB signaling, as BDNF modulates $\mathrm{GAD}_{65}$ and $\mathrm{GAD}_{67}$ expression following SCI [23] (Figure 1B). This is in agreement with the dual role of BDNF in preventing or promoting downstream pathways depending on the surrounding cellular environment $[73,116]$ (further discussed in Section 2.5).

\subsection{Chloride Homeostasis}

The alterations in inhibitory synaptic transmission after SCI are not only due to a general change in markers of inhibition (Section 2.4), but also to changes in the cation chloride co-transporters KCC2 (and/or NKCC1) that regulate intracellular chloride levels $\left(\left[\mathrm{Cl}^{-}\right]_{\mathrm{i}}\right)$ required for inhibition $[36,51,73,87,117-119] . \quad\left[\mathrm{Cl}^{-}\right]_{\mathrm{i}}$ is largely governed by the cation chloride cotransporters KCC2 (chloride extruder) and NKCC1 (chloride intruder) [120]. Their relative expression determines the chloride reversal potential, and thus regulates the amplitude and polarity of GABAergic and glycinergic responses. After SCI, there is a sudden and severe reduction in excitability of neurons below the lesion, due in part to the lack of serotonergic neuromodulation that normally emanates from descending tracts. This causes the sub-lesional cord to recapitulate a state observed during early development: $\mathrm{KCC} 2$ is downregulated, $\mathrm{Cl}^{-}$ions accumulate within the neurons, and GABA- and glycine-mediated responses are less hyperpolarizing, and can even be depolarizing $[73,121]$ (Figure 1B). The importance of this shift is revealed by its involvement in the development of both spasticity and neuropathic pain after SCIs [73,122,123].

Exercise improves these symptoms in the clinic [124,125], and recent studies from animal models of SCI suggest that these improvements are associated with an increase in expression of KCC2 around motoneurons below the lesion [20,36,46,51,62,87]. Moreover, KCC2 was identified as both necessary and sufficient for these effects. Exercise-induced improvements in spasticity are mimicked by a single dose of a KCC2-enhancing compound in unexercised rats with SCI [126], and are eliminated when KCC2 activity is blocked during exercise [62]. This effect was found to rely on BDNF/TrkB signaling, as chelating BDNF with TrkB-IgG during exercise prevented both the upregulation of KCC2 and the exercise-dependent functional improvements [46,62]. This provides evidence that beyond 
modulating classical synaptic plasticity, the activity-dependent increase in BDNF is also a robust mediator of ionic plasticity.

Importantly, the regulation of KCC2 by BDNF changes following SCI, with BDNF promoting KCC2 expression after injury, rather than downregulating it [73,116]. Potential mechanisms driving this change remain to be fully explored, but a likely possibility is the contribution of PLC $\gamma$ (Phospholipase C) and Shc [127-129]. BDNF has been shown to induce an increase in Shc and downregulate KCC2 when PLC- $\gamma$ is present, but upregulate KCC2 when PLC- $\gamma$ is absent $[127,128]$. Fittingly, expression of PLC $-\gamma$ is reduced within 14 days following SCI [46] (Figure 1B). While exercise increases the expression of BDNF, it does not impact the expression of PLC- $\gamma$ (Table 1), and therefore leads to KCC2 upregulation [46]. Interestingly, the increase in KCC2 with exercise is also paralleled by a significant preservation of spinal PNNs [20]. The proteoglycans found in PNNs can contribute to chloride homeostasis and the polarity of GABA signaling [130]. The simultaneous increase in KCC2 expression on motoneurons and increase in synthesis of PNN components during development $[131,132]$ suggests a potential relationship between these markers that can be reversed by exercise. Together, this suggests that chloride homeostasis may play an important role in the homeostatic effects observed with exercise.

Additionally, $5-\mathrm{HT}_{2 \mathrm{~A}} \mathrm{R}$ have also been implicated in the regulation of $\mathrm{KCC} 2$ in the spinal cord [73]. After $\mathrm{SCI}$, the pharmacological activation of $5-\mathrm{HT}_{2 \mathrm{~A}} \mathrm{R}$, which hyperpolarizes the reversal potential of inhibitory postsynaptic potentials (IPSPs), increases cell membrane expression of KCC2 and restores endogenous inhibition [117]. While some studies have found exercise to increase the expression of the 5- $\mathrm{HT}_{2 \mathrm{~A}} \mathrm{R}$ following SCI [35,87], whether this contributes to the upregulation of KCC2 in synergy with the BDNF pathway remains to be determined.

\section{Rehabilitation Promotes Sprouting and Regeneration}

Beyond synaptogenesis and the strengthening of existing pathways, anatomical plasticity in response to exercise after $\mathrm{SCI}$ also includes axonal growth, regeneration through the core of the lesion, sprouting of spared neural tissue, and the formation of novel relays. The remodeling of spinal cord connectivity can also be triggered by increased sprouting and plasticity of axonal connections.

\subsection{Serotoninergic Fiber Sprouting}

Injury-induced sprouting has been shown to be enhanced by exercise such as treadmill training or wheel running $[17,27,133-136]$. However, very little is known about the signaling pathways contributing to these changes, as they have mostly been identified in terms of which supraspinal pathway is involved. Due to its vital role in supraspinal modulation, serotonin is often a focus of these studies.

Beyond changes in the expression of spinal 5-HT receptors induced by exercise (Section 2.3), supraspinal serotoninergic projections that are spared after an incomplete SCI can also undergo plastic changes. Serotoninergic projections originating from the raphe nuclei extend to motoneurons in the ventral horn of the spinal cord to regulate their activity. It has been long known that increasing serotonergic activity with exogenous serotonergic agonists facilitates stepping after SCI in animal models [137-139], and that the presence of 5-HT fibers and terminals in the spinal cord and the recovery of locomotor function after injury is strongly correlated [140-143]. Exercise was shown to increase (1) 5-HT fiber outgrowth, (2) the number of 5-HT fibers, and (3) the amount of presynaptic terminals around motoneurons in the ventral horn caudal to an incomplete injury (Figure 1A). In agreement with earlier studies, this was associated with functional recovery, including improvements in locomotion and reaching/grasping $[22,133,136]$. Although the causality of this relationship remains to be determined, this suggests that exercise can promote axonal sprouting to supplement the loss of 5-HT supply and improve function. Potential mechanisms for this likely involve exercise-induced increases in BDNF, as it is implicated in 
structural changes in the lumbar spinal cord following SCI, including increased sprouting of serotonergic axons [133].

\subsection{Markers of Regeneration}

Perhaps the most obvious approach to treat SCI is to reestablish communication between the separated segments of the CNS. Axonal regeneration was long considered the gold standard to cure SCI by achieving regrowth across the lesion site. However, several decades of research have proven it is not a trivial endeavor [144]. In that context, exercise is mostly used to guide regenerating axons towards creating functional circuits. This is a critical step, as without appropriate guidance, newly formed connections are likely to reach inappropriate targets and lead to maladaptive plasticity and aberrant function $[145,146]$.

A very limited number of studies have focused on the effect of exercise alone on regeneration, perhaps because early studies suggested that exercise only modestly impacts axon regeneration across the lesion site and might not be sufficient to induce robust recovery [147-149]. However, any treatment aiming to be translatable to the clinic needs to include a rehabilitation program, as it is incorporated in the standard of care. In any case, there is now a consensus that an effective treatment for SCI will require the inclusion of activity-based therapy to promote functional recovery and effectively enhance neuroplasticity $[15,147,150]$. Most often, exercise is combined with pharmacological and/or surgical approaches to manipulate neuronal intrinsic growth programs that encourage axon regeneration. These include peripheral nerve grafts (PNG) [148,151], neural stem-cell grafts $[149,152]$, and enzymes that degrade inhibitors of axon regeneration $[27,153,154]$, all of which contribute to establishing a growth and plasticity permissive environment [148-151].

To date, there are no convincing data supporting a role for exercise in increasing the regenerative potential and improving function in SCI models of regeneration [155-158]. However, a number of anatomical changes were identified. For example, cycling exercise has been shown to increase propriospinal regeneration into a PNG and modulate the expression of genes associated with regeneration, including mRNA levels for GAP43 and $\beta$-actin, both involved in axon elongation, and neuritin, which promotes synapse formation and neurite outgrowth [148] (Figure 1C). Similarly, combining neural stem-cell grafts with treadmill training significantly improved regenerative capability after contusion injury in mice by increasing the number of Elavl ${ }^{+}$cells, suggesting that exercise facilitated neuronal differentiation within the stem-cell graft [149]. The addition of treadmill training also increased the immunoreactivity of pGAP43 in the spinal cord caudal to the injury site, and was accompanied by a significant increase in other molecules that regulate synaptic plasticity, such as VGlut1, $\mathrm{GAD}_{65}$, and Synapsin I, as well as functional improvements in reflex inhibition. While this is encouraging, results still remain limited in terms of functional recovery, especially after chronic SCI [149,152].

\subsection{Bypassing the Lesion}

Long descending supraspinal tracts are particularly susceptible to damage by an SCI. As such, a substantial amount of supraspinal rewiring takes place at a distance from the lesion, and it is now well known that this is important for recovery [159-162]. There are several detour pathways that have been shown to relay information from supraspinal locomotor commands through the lesion site after incomplete SCI. Amongst these pathways, the contribution of exercise to the corticospino-propriospinal pathway [159] and the corticospino-reticulospinal pathway [163] are the best described.

In rats [159] and in humans [164], combining electrical stimulation of the spinal cord with locomotor training improves voluntary control of overground stepping even when stimulation is discontinued, suggesting that adding training to the neuromodulatory treatment is essential to shape the circuitry in a meaningful manner [159]. These new circuits arise when collaterals of transected corticospinal fibers migrate into the grey matter to contact neurons of either the long propriospinal tract $[136,159]$ or the reticulospinal 
tract [163]. These subsequently bypass the lesion site to contact lumbar motoneurons, and form cortically controlled detour pathways [136,165]. Even without the addition of neuromodulatory treatments, rehabilitation provided via irregular running wheels was shown to increase formation of these circuits up to threefold [136] (Figure 1C). The rewiring persisted for many weeks and was accompanied by improvements in skilled motor tasks, which depend on corticospinal input. Interestingly, uninjured animals that underwent the same rehabilitative program showed no such changes in circuitry, suggesting that this effect of exercise on circuit plasticity is specific to damaged pathways [136].

\section{Other Considerations}

Beyond the damage incurred by the lesion itself, known as the primary mechanical injury, there are further mechanisms of damage that follow. Inflammation, neural and glial cell death, and maladaptive immune responses all contribute to what is known as the secondary injury, which leads to expansion of the initial damage to more distal segments of the cord [166]. Although most of these factors are studied in terms of their contribution to lesion size and neuropathic pain after SCI, which is not the focus of this review, they also have the potential to affect motor recovery. By destroying the blood-spinal-cord barrier, an SCI allows blood-borne neutrophils to flood into the lesion site. This triggers a near-immediate upsurge in inflammatory mediators, such as TNF- $\alpha$ and IL- $1 \beta$, as well as activation of microglia $[167,168]$ (Figure 1C).

Inflammation after SCI induces an abundant number of complications, including activation of multiple apoptotic signaling proteins and the subsequent death of neurons and oligodendrocytes (demyelination) [168]. Several studies have found that exercise reduces expression of inflammatory markers after SCI in animal models $[169,170]$ and in humans [171], but how this occurs has yet to be clearly delineated. While there are numerous mechanisms likely at play, one possibility is via an increase in vascular endothelial growth factor (VEGF). VEGF promotes endothelial cell proliferation, vascularization, and angiogenesis, and is upregulated by exercise via lactate receptors expressed in the blood-brain barrier [172]. After SCI, the exercise-induced increase in VEGF is associated with enhanced expression of tight junctions and adherens junctions, which reduces blood-spinal-cord barrier permeability and improves locomotor recovery [173]. This effect was further shown to rely on BDNF/TrkB signaling [47], as well as inhibition of matrix metalloproteinases (MMPs) [173], which restructure extracellular matrices and damage the blood-spinal-cord barrier after SCI [174,175]. Interestingly, another study found that after SCI, proliferating endothelial cells located in the core of the lesion upregulate CD200, which hinders inflammation [176], while yet another study found that treadmill exercise upregulates both CD200 and its receptor after stroke in rats [177]. Thus, it is possible that the decrease in inflammatory signaling observed with exercise occurs in part by increasing the endothelial release of CD200 and increasing the expression of the CD200 receptor. However, this has yet to be investigated in a model of SCI.

The local responses of glial cells, astrocytes and oligodendrocytes in particular, are also a critical determinant of motor recovery, as they contribute to the non-permissible environment limiting axon regeneration [178]. Rehabilitation significantly decreases glial fibrillary acidic protein $(\mathrm{GFAP})^{+}$astrogliosis, i.e., reactive astrocytes and their deposition of extracellular matrix molecules, such as CSPGs, both in the epicenter and in the spinal cord caudal to the lesion [22,136] (Figure 1C). As astrogliosis inhibits axonal growth through the formation of the glial scar after SCI, this suggests that rehabilitation can modify the injury environment and improve functional recovery. Similarly, it was found that exercise reduces microglia activation in the spinal cord [179], though there remains substantial ambiguity surrounding microglia and their effect on motor recovery.

\section{Potential for Translation and Limitations}

Following SCI, exercise-based therapies are associated with countless forms of plasticity, ranging from circuit formation, prevention of apoptosis, axonal sprouting, changes in 
chloride homeostasis, and many other alterations that likely contribute to neural repair and functional recovery. While the mechanisms responsible for this activity-dependent plasticity remain to be completely described, there is substantial evidence implicating the upregulation of neurotrophins as a cardinal regulator of these processes.

As a result of its versatility and non-invasive nature, exercise is routinely used in the clinic as a strategy to improve motor recovery. While there is abundant evidence supporting improved functional recovery and quality of life with exercise and activity-based therapies after SCI in humans, the number of randomized controlled clinical trials remains limited, and shows considerable variability across studies and patients in response to therapy $[180,181]$. Amongst the critical limitations of clinical trials is the need to standardize therapy, while in the clinic, activity-based therapies need to be highly individualized, both in modality and intensity based on specific needs to optimize functional improvements. In addition, the many co-morbidities that accompany SCI can make exercise challenging or even impossible for some individuals, particularly early after injury. Thus, there remains a need for pharmacological therapies that can be combined with exercise or substituted for exercise when necessary. Caution is warranted, however, as pharmacological interventions produce systemic changes in signaling, unlike exercise, which, by inducing neural activity in relevant networks, alters molecular pathways in a more finely tuned, spatio-temporal manner.

Nonetheless, it is now widely accepted that to significantly regain motor function after an SCI, it will necessitate a combination of cellular and pharmacological treatments that address the variety of targets and processes affected by the SCI, and that these approaches are more robust when combined with activity-based therapies [15,182]. Optimizing these strategies will critically rely on a firm understanding of the molecular pathways involved in recovery, many of which were identified by investigating the effect of activity-based therapies in animal models of SCI. Finally, future therapeutic developments would benefit greatly from bench studies that consider the injury model and severity, the type of exercise provided, appropriate timing for initiation, as well as the spinal region of interest.

Table 1. Table summarizing key molecular changes in the spinal cord below the lesion after SCI and with exercise.

\begin{tabular}{|c|c|c|c|c|}
\hline Section & Chronic SCI & References & Chronic SCI + Exercise & References \\
\hline 2.1. Synaptic Plasticity & $\begin{array}{l}\downarrow \text { CREB } \\
\downarrow \text { Synapsin I } \\
\downarrow \text { Synaptophysin } \\
\downarrow \text { PSD-95 } \\
\downarrow \text { PNN }\end{array}$ & $\begin{array}{l}{[19,23]} \\
{[19,54]} \\
{[18,19,183]} \\
{[17]} \\
{[20,27]}\end{array}$ & $\begin{array}{l}\uparrow \text { CREB } \\
\uparrow \text { Synapsin I } \\
\uparrow \text { Synaptophysin } \\
\uparrow \text { PSD-95 } \\
\uparrow \text { PNN }\end{array}$ & $\begin{array}{l}{[19,23,54]} \\
{[19,22,54]} \\
{[17,28]} \\
{[17]} \\
{[20,27]}\end{array}$ \\
\hline 2.2. Neurotrophins & $\downarrow \mathrm{BDNF}$ & {$[18,19,23,45,51,54]$} & $\uparrow \mathrm{BDNF}$ & {$[18,19,23,44-47,51,54]$} \\
\hline 2.3. Serotonin Receptors & $\begin{array}{l}\uparrow 5-\mathrm{HT}_{1 \mathrm{~A}} \\
\uparrow 5-\mathrm{HT}_{2 \mathrm{~A}} \\
\uparrow 5-\mathrm{HT}_{2 \mathrm{C}} \\
\end{array}$ & $\begin{array}{l}{[35,86]} \\
{[35,87-92]} \\
{[79,81,93]} \\
\end{array}$ & $\begin{array}{l}\uparrow 5-\mathrm{HT}_{1 \mathrm{~A}} \\
\uparrow 5-\mathrm{HT}_{2 \mathrm{~A}} \\
=5-\mathrm{HT}_{2 \mathrm{C}}\end{array}$ & $\begin{array}{l}{[35]} \\
{[35,87]} \\
{[87]}\end{array}$ \\
\hline \multirow{4}{*}{$\begin{array}{l}\text { 2.4. Markers of } \\
\text { in inhibition }\end{array}$} & $\uparrow \downarrow$ GlyR & $\begin{array}{l}\uparrow[37] \\
=[36] \\
\downarrow[114]\end{array}$ & $\downarrow \uparrow$ GlyR & $\begin{array}{l}\downarrow[37] \\
\uparrow[36]\end{array}$ \\
\hline & $\uparrow \downarrow \mathrm{GABA}_{\mathrm{A}} \mathrm{R}$ & $\begin{array}{l}\uparrow \downarrow[107] \\
\downarrow[114]\end{array}$ & $\downarrow \uparrow \mathrm{GABA}_{\mathrm{A}} \mathrm{R}$ & $\uparrow \downarrow[107]$ \\
\hline & $\uparrow \downarrow \mathrm{GAD}_{67}$ & $\begin{array}{l}\uparrow[106] \\
\downarrow[23]\end{array}$ & $\downarrow \uparrow \mathrm{GAD}_{67}$ & {$[25,45]$} \\
\hline & $\uparrow \downarrow \mathrm{GAD}_{65}$ & $\begin{array}{l}=[36,106] \\
\downarrow[23]\end{array}$ & $\uparrow \downarrow \mathrm{GAD}_{65}$ & $\begin{array}{l}\uparrow[23] \\
=[43] \\
\uparrow \downarrow[36]\end{array}$ \\
\hline $\begin{array}{l}\text { 2.5. Chloride } \\
\text { Homeostasis }\end{array}$ & $\begin{array}{l}\downarrow \mathrm{KCC} 2 \\
\downarrow \mathrm{PLC} \gamma\end{array}$ & $\begin{array}{l}{[20,36,51,62,73,87]} \\
{[46]}\end{array}$ & $\begin{array}{l}\uparrow \mathrm{KCC} 2 \\
=\mathrm{PLC} \gamma\end{array}$ & $\begin{array}{l}{[20,36,46,51,62,87]} \\
{[46]}\end{array}$ \\
\hline
\end{tabular}

Legend: $\uparrow$ increased, $\downarrow$ decreased, $=$ no change, $\uparrow \downarrow$ increased or decreased depending on location.

Author Contributions: J.N.B., G.C., and M.-P.C. designed the review outline; J.N.B. and M.-P.C. drafted the manuscript; and G.C. provided critical review of the manuscript. All authors have read and agreed to the published version of the manuscript.

Funding: This work was supported by the National Institute of Health (NS083666 and NS119475), the Craig H. Neilsen Foundation (647897) and the Department of Defense (SC190008). 
Institutional Review Board Statement: Not applicable.

Informed Consent Statement: Not applicable.

Data Availability Statement: Not applicable.

Conflicts of Interest: The authors declare no conflict of interest.

\section{References}

1. National Spinal Cord Injury Statistical Center. Facts and Figures at a Glance; University of Alabama at Birmingham: Birmingham, AL, USA, 2021.

2. Legg Ditterline, B.E.; Aslan, S.C.; Randall, D.C.; Harkema, S.J.; Castillo, C.; Ovechkin, A.V. Effects of Respiratory Training on Heart Rate Variability and Baroreflex Sensitivity in Individuals With Chronic Spinal Cord Injury. Arch. Phys. Med. Rehabil. 2018, 99, 423-432. [CrossRef]

3. Terson de Paleville, D.; McKay, W.; Aslan, S.; Folz, R.; Sayenko, D.; Ovechkin, A. Locomotor step training with body weight support improves respiratory motor function in individuals with chronic spinal cord injury. Respir. Physiol. Neurobiol. 2013, 189, 491-497. [CrossRef]

4. Mueller, G.; Hopman, M.T.; Perret, C. Comparison of respiratory muscle training methods in individuals with motor and sensory complete tetraplegia: A randomized controlled trial. J. Rehabil. Med. 2013, 45, 248-253. [CrossRef] [PubMed]

5. Onushko, T.; Mahtani, G.B.; Brazg, G.; Hornby, T.G.; Schmit, B.D. Exercise-Induced Alterations in Sympathetic-Somatomotor Coupling in Incomplete Spinal Cord Injury. J. Neurotrauma 2019, 36, 2688-2697. [CrossRef]

6. Ginis, K.A.; Hicks, A.L.; Latimer, A.E.; Warburton, D.E.; Bourne, C.; Ditor, D.S.; Goodwin, D.L.; Hayes, K.C.; McCartney, N.; McIlraith, A.; et al. The developMent. of evidence-inforMed. physical activity guidelines for adults with spinal cord injury. Spinal Cord 2011, 49, 1088-1096. [CrossRef] [PubMed]

7. Hubscher, C.H.; Herrity, A.N.; Williams, C.S.; Montgomery, L.R.; Willhite, A.M.; Angeli, C.A.; Harkema, S.J. Improvements in bladder, bowel and sexual outcomes following task-specific locomotor training in human spinal cord injury. PLoS ONE 2018, 13, e0190998. [CrossRef]

8. Morrison, S.A.; Lorenz, D.; Eskay, C.P.; Forrest, G.F.; Basso, D.M. Longitudinal Recovery and Reduced Costs After 120 Sessions of Locomotor Training for Motor Incomplete Spinal Cord Injury. Arch. Phys. Med. Rehabil. 2018, 99, 555-562. [CrossRef] [PubMed]

9. Harkema, S.J.; Hillyer, J.; Schmidt-Read, M.; Ardolino, E.; Sisto, S.A.; Behrman, A.L. Locomotor training: As a treatMent. of spinal cord injury and in the progression of neurologic rehabilitation. Arch. Phys. Med. Rehabil. 2012, 93, 1588-1597. [CrossRef]

10. Kaiser, A.; Chan, K.; Pakosh, M.; Musselman, K.E. Characteristics of activity-based therapy interventions for people living with spinal cord injury or disease across the continuum of care: A scoping review protocol. BMJ. Open 2020, 10, e040014. [CrossRef]

11. Tse, C.M.; Chisholm, A.E.; Lam, T.; Eng, J.J.; Team, S.R. A systematic review of the effectiveness of task-specific rehabilitation interventions for improving independent sitting and standing function in spinal cord injury. J. Spinal Cord Med. 2018, 41, 254-266. [CrossRef]

12. Rejc, E.; Angeli, C.A.; Atkinson, D.; Harkema, S.J. Motor recovery after activity-based training with spinal cord epidural stimulation in a chronic motor complete paraplegic. Sci. Rep. 2017, 7, 13476. [CrossRef]

13. Rejc, E.; Angeli, C.A.; Bryant, N.; Harkema, S.J. Effects of Stand and Step Training with Epidural Stimulation on Motor Function for Standing in Chronic Complete Paraplegics. J. Neurotrauma 2017, 34, 1787-1802. [CrossRef] [PubMed]

14. Harkema, S.; Behrman, A.; Barbeau, H. Evidence-based therapy for recovery of function after spinal cord injury. Handb. Clin. Neurol. 2012, 109, 259-274. [CrossRef]

15. Côté, M.-P.; Murray, M.; Lemay, M.A. Rehabilitation Strategies after Spinal Cord Injury: Inquiry into the Mechanisms of Success and Failure. J. Neurotrauma 2017, 34, 1841-1857. [CrossRef] [PubMed]

16. Martin Ginis, K.A.; van der Scheer, J.W.; Latimer-Cheung, A.E.; Barrow, A.; Bourne, C.; Carruthers, P.; Bernardi, M.; Ditor, D.S.; Gaudet, S.; de Groot, S.; et al. Evidence-based scientific exercise guidelines for adults with spinal cord injury: An update and a new guideline. Spinal Cord 2018, 56, 308-321. [CrossRef] [PubMed]

17. Goldshmit, Y.; Lythgo, N.; Galea, M.P.; Turnley, A.M. Treadmill training after spinal cord hemisection in mice promotes axonal sprouting and synapse formation and improves motor recovery. J. Neurotrauma 2008, 25, 449-465. [CrossRef]

18. Wang, H.; Liu, N.K.; Zhang, Y.P.; Deng, L.; Lu, Q.B.; Shields, C.B.; Walker, M.J.; Li, J.; Xu, X.M. Treadmill training induced lumbar motoneuron dendritic plasticity and behavior recovery in adult rats after a thoracic contusive spinal cord injury. Exp. Neurol. 2015, 271, 368-378. [CrossRef]

19. Ying, Z.; Roy, R.R.; Edgerton, V.R.; Gomez-Pinilla, F. Exercise restores levels of neurotrophins and synaptic plasticity following spinal cord injury. Exp. Neurol. 2005, 193, 411-419. [CrossRef] [PubMed]

20. Sanchez-Ventura, J.; Gimenez-Llort, L.; Penas, C.; Udina, E. Voluntary wheel running preserves lumbar perineuronal nets, enhances motor functions and prevents hyperreflexia after spinal cord injury. Exp. Neurol. 2021, 336, 113533. [CrossRef]

21. Petruska, J.C.; Ichiyama, R.M.; Jindrich, D.L.; Crown, E.D.; Tansey, K.E.; Roy, R.R.; Edgerton, V.R.; Mendell, L.M. Changes in motoneuron properties and synaptic inputs related to step training after spinal cord transection in rats. J. Neurosci. 2007, 27, 4460-4471. [CrossRef]

22. Gallegos, C.; Carey, M.; Zheng, Y.; He, X.; Cao, Q.L. Reaching and Grasping Training Improves Functional Recovery After Chronic Cervical Spinal Cord Injury. Front. Cell Neurosci. 2020, 14, 110. [CrossRef] 
23. Li, X.; Wang, Q.; Ding, J.; Wang, S.; Dong, C.; Wu, Q. Exercise training modulates glutamic acid decarboxylase-65/67 expression through TrkB signaling to ameliorate neuropathic pain in rats with spinal cord injury. Mol. Pain 2020, 16, 1744806920924511. [CrossRef] [PubMed]

24. Ying, S.W.; Futter, M.; Rosenblum, K.; Webber, M.J.; Hunt, S.P.; Bliss, T.V.; Bramham, C.R. Brain-derived neurotrophic factor induces long-term potentiation in intact adult hippocampus: RequireMent. for ERK activation coupled to CREB and upregulation of Arc synthesis. J. Neurosci. 2002, 22, 1532-1540. [CrossRef] [PubMed]

25. Walton, M.; Connor, B.; Lawlor, P.; Young, D.; Sirimanne, E.; Gluckman, P.; Cole, G.; Dragunow, M. Neuronal death and survival in two models of hypoxic-ischemic brain damage. Brain Res. Brain Res. Rev. 1999, 29, 137-168. [CrossRef]

26. Smith, C.C.; Mauricio, R.; Nobre, L.; Marsh, B.; Wust, R.C.; Rossiter, H.B.; Ichiyama, R.M. Differential regulation of perineuronal nets in the brain and spinal cord with exercise training. Brain Res. Bull. 2015, 111, 20-26. [CrossRef]

27. Wang, D.; Ichiyama, R.M.; Zhao, R.; Andrews, M.R.; Fawcett, J.W. Chondroitinase combined with rehabilitation promotes recovery of forelimb function in rats with chronic spinal cord injury. J. Neurosci. 2011, 31, 9332-9344. [CrossRef]

28. Kwok, J.C.; Afshari, F.; Garcia-Alias, G.; Fawcett, J.W. Proteoglycans in the central nervous system: Plasticity, regeneration and their stimulation with chondroitinase ABC. Restor. Neurol. Neurosci. 2008, 26, 131-145.

29. Fawcett, J.W.; Oohashi, T.; Pizzorusso, T. The roles of perineuronal nets and the perinodal extracellular matrix in neuronal function. Nat. Rev. Neurosci. 2019, 20, 451-465. [CrossRef]

30. Pizzorusso, T.; Medini, P.; Berardi, N.; Chierzi, S.; Fawcett, J.W.; Maffei, L. Reactivation of ocular dominance plasticity in the adult visual cortex. Science 2002, 298, 1248-1251. [CrossRef]

31. Arbat-Plana, A.; Torres-Espin, A.; Navarro, X.; Udina, E. Activity dependent therapies modulate the spinal changes that motoneurons suffer after a peripheral nerve injury. Exp. Neurol. 2015, 263, 293-305. [CrossRef]

32. Gomez-Pinilla, F.; Ying, Z.; Roy, R.R.; Molteni, R.; Edgerton, V.R. Voluntary exercise induces a BDNF-mediated mechanism that promotes neuroplasticity. J. Neurophysiol. 2002, 88, 2187-2195. [CrossRef]

33. Kawasaki, A.; Okada, M.; Tamada, A.; Okuda, S.; Nozumi, M.; Ito, Y.; Kobayashi, D.; Yamasaki, T.; Yokoyama, R.; Shibata, T.; et al. Growth Cone Phosphoproteomics Reveals that GAP-43 Phosphorylated by JNK Is a Marker of Axon Growth and Regeneration. Science 2018, 4, 190-203. [CrossRef] [PubMed]

34. Bandaru, S.P.; Liu, S.; Waxman, S.G.; Tan, A.M. Dendritic spine dysgenesis contributes to hyperreflexia after spinal cord injury. J. Neurophysiol. 2015, 113, 1598-1615. [CrossRef]

35. Ganzer, P.D.; Beringer, C.R.; Shumsky, J.S.; Nwaobasi, C.; Moxon, K.A. Serotonin receptor and dendritic plasticity in the spinal cord mediated by chronic serotonergic pharmacotherapy combined with exercise following complete SCI. in the adult rat. Exp. Neurol. 2018, 304, 132-142. [CrossRef]

36. Khalki, L.; Sadlaoud, K.; Lerond, J.; Coq, J.O.; Brezun, J.M.; Vinay, L.; Coulon, P.; Bras, H. Changes in innervation of lumbar motoneurons and organization of premotor network following training of transected adult rats. Exp. Neurol. 2018, $299,1-14$. [CrossRef]

37. Edgerton, V.R.; Leon, R.D.; Harkema, S.J.; Hodgson, J.A.; London, N.; Reinkensmeyer, D.J.; Roy, R.R.; Talmadge, R.J.; Tillakaratne, N.J.; Timoszyk, W.; et al. Retraining the injured spinal cord. J. Physiol. 2001, 533, 15-22. [CrossRef]

38. Huang, E.J.; Reichardt, L.F. Neurotrophins: Roles in neuronal developMent. and function. Annu. Rev. Neurosci. 2001, 24, 677-736. [CrossRef] [PubMed]

39. Keefe, K.M.; Sheikh, I.S.; Smith, G.M. Targeting Neurotrophins to Specific Populations of Neurons: NGF, BDNF, and NT-3 and Their Relevance for TreatMent. of Spinal Cord Injury. Int. J. Mol. Sci. 2017, 18, 548. [CrossRef]

40. Gomez-Pinilla, F.; Huie, J.R.; Ying, Z.; Ferguson, A.R.; Crown, E.D.; Baumbauer, K.M.; Edgerton, V.R.; Grau, J.W. BDNF and learning: Evidence that instrumental training promotes learning within the spinal cord by up-regulating BDNF expression. Neuroscience 2007, 148, 893-906. [CrossRef] [PubMed]

41. Lu, B. BDNF and activity-dependent synaptic modulation. Learn. Mem. 2003, 10, 86-98. [CrossRef]

42. Neeper, S.A.; Gomez-Pinilla, F.; Choi, J.; Cotman, C. Exercise and brain neurotrophins. Nature 1995, 373, 109. [CrossRef] [PubMed]

43. Tillakaratne, N.J.; De Leon, R.D.; Hoang, T.X.; Roy, R.R.; Edgerton, V.R.; Tobin, A.J. Use-dependent modulation of inhibitory capacity in the feline lumbar spinal cord. J. Neurosci. 2002, 22, 3130-3143. [CrossRef]

44. Côté, M.-P.; Azzam, G.A.; Lemay, M.A.; Zhukareva, V.; Houle, J.D. Activity-dependent increase in neurotrophic factors is associated with an enhanced modulation of spinal reflexes after spinal cord injury. J. Neurotrauma 2011, 28, 299-309. [CrossRef]

45. Hutchinson, K.J.; Gomez-Pinilla, F.; Crowe, M.J.; Ying, Z.; Basso, D.M. Three exercise paradigms differentially improve sensory recovery after spinal cord contusion in rats. Brain 2004, 127, 1403-1414. [CrossRef] [PubMed]

46. Tashiro, S.; Shinozaki, M.; Mukaino, M.; Renault-Mihara, F.; Toyama, Y.; Liu, M.; Nakamura, M.; Okano, H. BDNF Induced by Treadmill Training Contributes to the Suppression of Spasticity and Allodynia After Spinal Cord Injury via Upregulation of KCC2. Neurorehabil. Neural Repair 2015, 29, 677-689. [CrossRef]

47. Ying, X.; Xie, Q.; Yu, X.; Li, S.; Wu, Q.; Chen, X.; Yue, J.; Zhou, K.; Tu, W.; Jiang, S. Water treadmill training protects the integrity of the blood-spinal cord barrier following SCI. via the BDNF/TrkB-CREB signalling pathway. Neurochem. Int. 2021, 143, 104945. [CrossRef]

48. Goldhardt, M.G.; Andreia, A.; Dorneles, G.P.; da Silva, I.R.; Pochmann, D.; Peres, A.; Rostirola Elsner, V. Does a single bout of exercise impacts BDNF, oxidative stress and epigenetic markers in spinal cord injury patients? Funct. Neurol. 2019, 34, 158-166. 
49. Leech, K.A.; Hornby, T.G. High-Intensity Locomotor Exercise Increases Brain-Derived Neurotrophic Factor in Individuals with Incomplete Spinal Cord Injury. J. Neurotrauma 2017, 34, 1240-1248. [CrossRef]

50. Rojas Vega, S.; Abel, T.; Lindschulten, R.; Hollmann, W.; Bloch, W.; Struder, H.K. Impact of exercise on neuroplasticity-related proteins in spinal cord injured humans. Neuroscience 2008, 153, 1064-1070. [CrossRef] [PubMed]

51. Côté, M.-P.; Gandhi, S.; Zambrotta, M.; Houle, J.D. Exercise modulates chloride homeostasis after spinal cord injury. J. Neurosci. 2014, 34, 8976-8987. [CrossRef] [PubMed]

52. Gomez-Pinilla, F.; Ying, Z.; Roy, R.R.; Hodgson, J.; Edgerton, V.R. Afferent input modulates neurotrophins and synaptic plasticity in the spinal cord. J. Neurophysiol. 2004, 92, 3423-3432. [CrossRef] [PubMed]

53. Dupont-Versteegden, E.E.; Houle, J.D.; Dennis, R.A.; Zhang, J.; Knox, M.; Wagoner, G.; Peterson, C.A. Exercise-induced gene expression in soleus muscle is dependent on time after spinal cord injury in rats. Muscle Nerve 2004, 29, 73-81. [CrossRef] [PubMed]

54. Ying, Z.; Roy, R.R.; Zhong, H.; Zdunowski, S.; Edgerton, V.R.; Gomez-Pinilla, F. BDNF-exercise interactions in the recovery of symmetrical stepping after a cervical hemisection in rats. Neuroscience 2008, 155, 1070-1078. [CrossRef]

55. Beaumont, E.; Kaloustian, S.; Rousseau, G.; Cormery, B. Training improves the electrophysiological properties of lumbar neurons and locomotion after thoracic spinal cord injury in rats. Neurosci. Res. 2008, 62, 147-154. [CrossRef]

56. Boyce, V.S.; Mendell, L.M. Neurotrophic factors in spinal cord injury. Handb. Exp. Pharmacol. 2014, 220, 443-460. [CrossRef]

57. Weishaupt, N.; Blesch, A.; Fouad, K. BDNF: The career of a multifaceted neurotrophin in spinal cord injury. Exp. Neurol. 2012, 238, 254-264. [CrossRef] [PubMed]

58. Thoenen, H. Neurotrophins and activity-dependent plasticity. Prog. Brain Res. 2000, 128, 183-191. [PubMed]

59. Jovanovic, J.N.; Czernik, A.J.; Fienberg, A.A.; Greengard, P.; Sihra, T.S. Synapsins as mediators of BDNF-enhanced neurotransmitter release. Nat. Neurosci. 2000, 3, 323-329. [CrossRef]

60. Vaynman, S.; Ying, Z.; Gomez-Pinilla, F. Interplay between brain-derived neurotrophic factor and signal transduction modulators in the regulation of the effects of exercise on synaptic-plasticity. Neuroscience 2003, 122, 647-657. [CrossRef] [PubMed]

61. Li, X.; Wu, Q.; Xie, C.; Wang, C.; Wang, Q.; Dong, C.; Fang, L.; Ding, J.; Wang, T. Blocking of BDNF-TrkB signaling inhibits the promotion effect of neurological function recovery after treadmill training in rats with spinal cord injury. Spinal Cord 2019, 57, 65-74. [CrossRef]

62. Beverungen, H.; Klaszky, S.C.; Klaszky, M.; Cote, M.P. Rehabilitation Decreases Spasticity by Restoring Chloride Homeostasis through the Brain-Derived Neurotrophic Factor-KCC2 Pathway after Spinal Cord Injury. J. Neurotrauma 2020, 37, 846-859. [CrossRef] [PubMed]

63. Sleiman, S.F.; Henry, J.; Al-Haddad, R.; El Hayek, L.; Abou Haidar, E.; Stringer, T.; Ulja, D.; Karuppagounder, S.S.; Holson, E.B.; Ratan, R.R.; et al. Exercise promotes the expression of brain derived neurotrophic factor (BDNF) through the action of the ketone body beta-hydroxybutyrate. Elife 2016, 5. [CrossRef]

64. Tao, X.; Finkbeiner, S.; Arnold, D.B.; Shaywitz, A.J.; Greenberg, M.E. Ca2+ influx regulates BDNF transcription by a CREB family transcription factor-dependent mechanism. Neuron 1998, 20, 709-726. [CrossRef]

65. Tao, X.; West, A.E.; Chen, W.G.; Corfas, G.; Greenberg, M.E. A calcium-responsive transcription factor, CaRF, that regulates neuronal activity-dependent expression of BDNF. Neuron 2002, 33, 383-395. [CrossRef]

66. Chen, W.G.; West, A.E.; Tao, X.; Corfas, G.; Szentirmay, M.N.; Sawadogo, M.; Vinson, C.; Greenberg, M.E. Upstream stimulatory factors are mediators of Ca2+-responsive transcription in neurons. J. Neurosci. 2003, 23, 2572-2581. [CrossRef]

67. Zhang, S.; Fujita, Y.; Matsuzaki, R.; Yamashita, T. Class I histone deacetylase (HDAC) inhibitor CI-994 promotes functional recovery following spinal cord injury. Cell Death Dis. 2018, 9, 460. [CrossRef]

68. Ying, Z.; Roy, R.R.; Edgerton, V.R.; Gomez-Pinilla, F. Voluntary exercise increases neurotrophin-3 and its receptor TrkC in the spinal cord. Brain Res. 2003, 987, 93-99. [CrossRef]

69. Skup, M.; Dwornik, A.; Macias, M.; Sulejczak, D.; Wiater, M.; Czarkowska-Bauch, J. Long-term locomotor training up-regulates $\operatorname{TrkB}(\mathrm{FL})$ receptor-like proteins, brain-derived neurotrophic factor, and neurotrophin 4 with different topographies of expression in oligodendroglia and neurons in the spinal cord. Exp. Neurol. 2002, 176, 289-307. [CrossRef]

70. Bregman, B.S.; Coumans, J.V.; Dai, H.N.; Kuhn, P.L.; Lynskey, J.; McAtee, M.; Sandhu, F. Transplants and neurotrophic factors increase regeneration and recovery of function after spinal cord injury. Prog. Brain Res. 2002, 137, 257-273.

71. Ollivier-Lanvin, K.; Fischer, I.; Tom, V.; Houle, J.D.; Lemay, M.A. Either brain-derived neurotrophic factor or neurotrophin-3 only neurotrophin-producing grafts promote locomotor recovery in untrained spinalized cats. Neurorehabil. Neural Repair 2015, 29 , 90-100. [CrossRef]

72. Boyce, V.S.; Park, J.; Gage, F.H.; Mendell, L.M. Differential effects of brain-derived neurotrophic factor and neurotrophin-3 on hindlimb function in paraplegic rats. Eur. J. Neurosci. 2012, 35, 221-232. [CrossRef] [PubMed]

73. Boulenguez, P.; Liabeuf, S.; Bos, R.; Bras, H.; Jean-Xavier, C.; Brocard, C.; Stil, A.; Darbon, P.; Cattaert, D.; Delpire, E.; et al. Down-regulation of the potassium-chloride cotransporter KCC2 contributes to spasticity after spinal cord injury. Nat. Med. 2010, 16, 302-307. [CrossRef]

74. Garraway, S.M.; Woller, S.A.; Huie, J.R.; Hartman, J.J.; Hook, M.A.; Miranda, R.C.; Huang, Y.J.; Ferguson, A.R.; Grau, J.W. Peripheral noxious stimulation reduces withdrawal threshold to mechanical stimuli after spinal cord injury: Role of tumor necrosis factor alpha and apoptosis. Pain 2014, 155, 2344-2359. [CrossRef] 
75. Lu, P.; Blesch, A.; Graham, L.; Wang, Y.; Samara, R.; Banos, K.; Haringer, V.; Havton, L.; Weishaupt, N.; Bennett, D.; et al. Motor axonal regeneration after partial and complete spinal cord transection. J. Neurosci. 2012, 32, 8208-8218. [CrossRef]

76. Fouad, K.; Bennett, D.J.; Vavrek, R.; Blesch, A. Long-term viral brain-derived neurotrophic factor delivery promotes spasticity in rats with a cervical spinal cord hemisection. Front. Neurol. 2013, 4, 187. [CrossRef]

77. de Leon, R.D.; See, P.A.; Chow, C.H. Differential effects of low versus high amounts of weight supported treadmill training in spinally transected rats. J. Neurotrauma 2011, 28, 1021-1033. [CrossRef]

78. Cha, J.; Heng, C.; Reinkensmeyer, D.J.; Roy, R.R.; Edgerton, V.R.; De Leon, R.D. Locomotor ability in spinal rats is dependent on the amount of activity imposed on the hindlimbs during treadmill training. J. Neurotrauma 2007, 24, 1000-1012. [CrossRef] [PubMed]

79. Murray, K.C.; Nakae, A.; Stephens, M.J.; Rank, M.; D'Amico, J.; Harvey, P.J.; Li, X.; Harris, R.L.; Ballou, E.W.; Anelli, R.; et al. Recovery of motoneuron and locomotor function after spinal cord injury depends on constitutive activity in 5-HT2C receptors. Nat. Med. 2010, 16, 694-700. [CrossRef]

80. Schmidt, B.J.; Jordan, L.M. The role of serotonin in reflex modulation and locomotor rhythm production in the mammalian spinal cord. Brain Res.Bull. 2000, 53, 689-710. [CrossRef]

81. Hayashi, Y.; Jacob-Vadakot, S.; Dugan, E.A.; McBride, S.; Olexa, R.; Simansky, K.; Murray, M.; Shumsky, J.S. 5-HT precursor loading, but not 5-HT receptor agonists, increases motor function after spinal cord contusion in adult rats. Exp. Neurol. 2010, 221, 68-78. [CrossRef] [PubMed]

82. Harvey, P.J.; Li, X.; Li, Y.; Bennett, D.J. 5-HT2 receptor activation facilitates a persistent sodium current and repetitive firing in spinal motoneurons of rats with and without chronic spinal cord injury. J. Neurophysiol. 2006, 96, 1158-1170. [CrossRef]

83. Chen, B.; Li, Y.; Yu, B.; Zhang, Z.; Brommer, B.; Williams, P.R.; Liu, Y.; Hegarty, S.V.; Zhou, S.; Zhu, J.; et al. Reactivation of Dormant Relay Pathways in Injured Spinal Cord by KCC2 Manipulations. Cell 2018, 174, 521-535.e13. [CrossRef] [PubMed]

84. Zhang, M. Normal Distribution and Plasticity of Serotonin Receptors After Spinal Cord Injury and Their Impacts on Motor Outputs. In Recovery of Motor Function Following Spinal Cord Injury; Fuller, H., Gates, M., Eds.; IntechOpen: London, UK, 2016. [CrossRef]

85. Slawinska, U.; Jordan, L.M. Serotonergic influences on locomotor circuits. Curr. Opin. Physiol. 2019, 8, 63-69. [CrossRef]

86. Otoshi, C.K.; Walwyn, W.M.; Tillakaratne, N.J.; Zhong, H.; Roy, R.R.; Edgerton, V.R. Distribution and localization of 5-HT(1A) receptors in the rat lumbar spinal cord after transection and deafferentation. J. Neurotrauma 2009, 26, 575-584. [CrossRef] [PubMed]

87. Chopek, J.W.; Sheppard, P.C.; Gardiner, K.; Gardiner, P.F. Serotonin receptor and KCC2 gene expression in lumbar flexor and extensor motoneurons posttransection with and without passive cycling. J. Neurophysiol. 2015, 113, 1369-1376. [CrossRef]

88. Ryu, Y.; Ogata, T.; Nagao, M.; Sawada, Y.; Nishimura, R.; Fujita, N. Effects of Treadmill Training Combined with Serotonergic Interventions on Spasticity after Contusive Spinal Cord Injury. J. Neurotrauma 2018, 35, 1358-1366. [CrossRef]

89. Lee, J.K.; Johnson, C.S.; Wrathall, J.R. Up-regulation of 5-HT2 receptors is involved in the increased H-reflex amplitude after contusive spinal cord injury. Exp. Neurol. 2007, 203, 502-511. [CrossRef] [PubMed]

90. Navarrett, S.; Collier, L.; Cardozo, C.; Dracheva, S. Alterations of serotonin 2C and 2A receptors in response to T10 spinal cord transection in rats. Neurosci. Lett. 2012, 506, 74-78. [CrossRef]

91. Kong, X.Y.; Wienecke, J.; Hultborn, H.; Zhang, M. Robust upregulation of serotonin 2A receptors after chronic spinal transection of rats: An immunohistochemical study. Brain Res. 2010, 1320, 60-68. [CrossRef]

92. Kong, X.Y.; Wienecke, J.; Chen, M.; Hultborn, H.; Zhang, M. The time course of serotonin 2A receptor expression after spinal transection of rats: An immunohistochemical study. Neuroscience 2011, 177, 114-126. [CrossRef]

93. Ren, L.Q.; Wienecke, J.; Chen, M.; Moller, M.; Hultborn, H.; Zhang, M. The time course of serotonin 2C receptor expression after spinal transection of rats: An immunohistochemical study. Neuroscience 2013, 236, 31-46. [CrossRef] [PubMed]

94. Fouad, K.; Rank, M.M.; Vavrek, R.; Murray, K.C.; Sanelli, L.; Bennett, D.J. Locomotion after spinal cord injury depends on constitutive activity in serotonin receptors. J. Neurophysiol. 2010, 104, 2975-2984. [CrossRef] [PubMed]

95. Gerasimenko, Y.; Gorodnichev, R.; Moshonkina, T.; Sayenko, D.; Gad, P.; Reggie Edgerton, V. Transcutaneous electrical spinal-cord stimulation in humans. Ann. Phys. Rehabil. Med. 2015, 58, 225-231. [CrossRef] [PubMed]

96. Gad, P.; Gerasimenko, Y.; Zdunowski, S.; Turner, A.; Sayenko, D.; Lu, D.C.; Edgerton, V.R. Weight Bearing Over-ground Stepping in an Exoskeleton with Non-invasive Spinal Cord Neuromodulation after Motor Complete Paraplegia. Front. Neurosci. 2017, 11, 333. [CrossRef] [PubMed]

97. Moshonkina, T.R.; Shapkova, E.Y.; Sukhotina, I.A.; Emeljannikov, D.V.; Gerasimenko, Y.P. Effect of Combination of Non-Invasive Spinal Cord Electrical Stimulation and Serotonin Receptor Activation in Patients with Chronic Spinal Cord Lesion. Bull. Exp. Biol. Med. 2016, 161, 749-754. [CrossRef]

98. Radhakrishna, M.; Steuer, I.; Prince, F.; Roberts, M.; Mongeon, D.; Kia, M.; Dyck, S.; Matte, G.; Vaillancourt, M.; Guertin, P.A. Double-Blind, Placebo-Controlled, Randomized Phase I/IIa Study (Safety and Efficacy) with Buspirone/Levodopa/Carbidopa (SpinalonTM) in Subjects with Complete AIS A or Motor-Complete AIS B Spinal Cord Injury. Curr. Pharm. Des. 2017, 23, 1789-1804. [CrossRef]

99. Takeoka, A.; Vollenweider, I.; Courtine, G.; Arber, S. Muscle spindle feedback directs locomotor recovery and circuit reorganization after spinal cord injury. Cell 2014, 159, 1626-1639. [CrossRef] 
100. Manohar, A.; Foffani, G.; Ganzer, P.D.; Bethea, J.R.; Moxon, K.A. Cortex-dependent recovery of unassisted hindlimb locomotion after complete spinal cord injury in adult rats. Elife 2017, 6. [CrossRef]

101. Foffani, G.; Shumsky, J.; Knudsen, E.B.; Ganzer, P.D.; Moxon, K.A. Interactive Effects Between Exercise and Serotonergic Pharmacotherapy on Cortical Reorganization After Spinal Cord Injury. Neurorehabil. Neural Repair 2016, 30, 479-489. [CrossRef]

102. Gonzalez-Maeso, J.; Sealfon, S.C. Psychedelics and schizophrenia. Trends Neurosci. 2009, 32, 225-232. [CrossRef]

103. Millan, M.J. Descending control of pain. Prog. Neurobiol. 2002, 66, 355-474. [CrossRef]

104. Kim, Y.S.; Yoon, B.E. Altered GABAergic Signaling in Brain Disease at Various Stages of Life. Exp. Neurobiol. 2017, 26, 122-131. [CrossRef] [PubMed]

105. Schmidt, R.W.; Thompson, M.L. Glycinergic signaling in the human nervous system: An overview of therapeutic drug targets and clinical effects. Ment. Health Clin. 2016, 6, 266-276. [CrossRef] [PubMed]

106. Tillakaratne, N.J.; Mouria, M.; Ziv, N.B.; Roy, R.R.; Edgerton, V.R.; Tobin, A.J. Increased expression of glutamate decarboxylase $(\mathrm{GAD}(67))$ in feline lumbar spinal cord after complete thoracic spinal cord transection. J. Neurosci. Res. 2000, 60, 219-230. [CrossRef]

107. Khristy, W.; Ali, N.J.; Bravo, A.B.; de, L.R.; Roy, R.R.; Zhong, H.; London, N.J.; Edgerton, V.R.; Tillakaratne, N.J. Changes in GABA(A) receptor subunit gamma 2 in extensor and flexor motoneurons and astrocytes after spinal cord transection and motor training. Brain Res. 2009, 1273, 9-17. [CrossRef] [PubMed]

108. Ichiyama, R.M.; Broman, J.; Roy, R.R.; Zhong, H.; Edgerton, V.R.; Havton, L.A. Locomotor training maintains normal inhibitory influence on both alpha- and gamma-motoneurons after neonatal spinal cord transection. J. Neurosci. 2011, 31, 26-33. [CrossRef]

109. Edgerton, V.R.; De Leon, R.D.; Tillakaratne, N.; Recktenwald, M.R.; Hodgson, J.A.; Roy, R.R. Use-dependent plasticity in spinal stepping and standing. Adv. Neurol. 1997, 72, 233-247. [PubMed]

110. Lim, B.V.; Shin, M.S.; Lee, J.M.; Seo, J.H. Treadmill exercise prevents GABAergic neuronal loss with suppression of neuronal activation in the pilocarpine-induced epileptic rats. J. Exerc. Rehabil. 2015, 11, 80-86. [CrossRef] [PubMed]

111. Kami, K.; Taguchi Ms, S.; Tajima, F.; Senba, E. Improvements in impaired GABA and GAD65/67 production in the spinal dorsal horn contribute to exercise-induced hypoalgesia in a mouse model of neuropathic pain. Mol. Pain 2016, 12. [CrossRef]

112. Farzad, B.; Rajabi, H.; Gharakhanlou, R.; Allison, D.J.; Hayat, P.; Jameie, S.B. Swimming Training Attenuates Allodynia and Hyperalgesia Induced by Peripheral Nerve Injury in an Adult Male Rat Neuropathic Model: Effects on Irisin and GAD65. Pain Med. 2018, 19, 2236-2245. [CrossRef] [PubMed]

113. Hill, L.E.; Droste, S.K.; Nutt, D.J.; Linthorst, A.C.; Reul, J.M. Voluntary exercise alters GABA(A) receptor subunit and glutamic acid decarboxylase-67 gene expression in the rat forebrain. J. Psychopharmacol. 2010, 24, 745-756. [CrossRef] [PubMed]

114. Sadlaoud, K.; Khalki, L.; Brocard, F.; Vinay, L.; Boulenguez, P.; Bras, H. Alteration of glycinergic receptor expression in lumbar spinal motoneurons is involved in the mechanisms underlying spasticity after spinal cord injury. J. Chem. Neuroanat. 2020, 106, 101787. [CrossRef] [PubMed]

115. Caron, G.; Bilchak, J.N.; Cote, M.P. Direct evidence for decreased presynaptic inhibition evoked by PBSt group I muscle afferents after chronic SCI. and recovery with step-training in rats. J. Physiol. 2020, 598, 4621-4642. [CrossRef] [PubMed]

116. Huang, Y.J.; Lee, K.H.; Grau, J.W. Complete spinal cord injury (SCI) transforms how brain derived neurotrophic factor (BDNF) affects nociceptive sensitization. Exp. Neurol. 2017, 288, 38-50. [CrossRef]

117. Bos, R.; Sadlaoud, K.; Boulenguez, P.; Buttigieg, D.; Liabeuf, S.; Brocard, C.; Haase, G.; Bras, H.; Vinay, L. Activation of 5-HT2A receptors upregulates the function of the neuronal K-Cl cotransporter KCC2. Proc. Natl. Acad. Sci. USA 2013, 110, 348-353. [CrossRef]

118. Jean-Xavier, C.; Pflieger, J.F.; Liabeuf, S.; Vinay, L. Inhibitory postsynaptic potentials in lumbar motoneurons remain depolarizing after neonatal spinal cord transection in the rat. J. Neurophysiol. 2006, 96, 2274-2281. [CrossRef]

119. Liabeuf, S.; Stuhl-Gourmand, L.; Gackiere, F.; Mancuso, R.; Sanchez Brualla, I.; Marino, P.; Brocard, F.; Vinay, L. Prochlorperazine Increases KCC2 Function and Reduces Spasticity after Spinal Cord Injury. J. Neurotrauma 2017, 34, 3397-3406. [CrossRef]

120. Delpire, E.; Mount, D.B. Human and murine phenotypes associated with defects in cation-chloride cotransport. Annu. Rev. Physiol. 2002, 64, 803-843. [CrossRef]

121. Huang, Y.J.; Grau, J.W. Ionic plasticity and pain: The loss of descending serotonergic fibers after spinal cord injury transforms how GABA affects pain. Exp. Neurol. 2018, 306, 105-116. [CrossRef] [PubMed]

122. Côté, M.-P. Role of chloride cotransporters in the development. of spasticity and neuropathic pain after spinal cord injury. In Neuronal Chloride Transporters in Health and Disease; Tang, X., Ed.; Academic Press: Cambridge, MA, USA, 2020; pp. 463-516. [CrossRef]

123. Sanchez-Brualla, I.; Boulenguez, P.; Brocard, C.; Liabeuf, S.; Viallat-Lieutaud, A.; Navarro, X.; Udina, E.; Brocard, F. Activation of 5-HT2A Receptors Restores KCC2 Function and Reduces Neuropathic Pain after Spinal Cord Injury. Neuroscience 2018, $387,48-57$. [CrossRef]

124. Elbasiouny, S.M.; Moroz, D.; Bakr, M.M.; Mushahwar, V.K. ManageMent. of spasticity after spinal cord injury: Current techniques and future directions. Neurorehabil. Neural Repair 2010, 24, 23-33. [CrossRef] [PubMed]

125. Petropoulou, K.B.; Panourias, I.G.; Rapidi, C.A.; Sakas, D.E. The importance of neurorehabilitation to the outcome of neuromodulation in spasticity. Acta Neurochir. Suppl. 2007, 97, 243-250.

126. Bilchak, J.; Yeakle, K.; Caron, G.; Malloy, D.; Cote, M.P. Enhancing KCC2 activity decreases hyperreflexia and spasticity after chronic spinal cord injury. Exp. Neurol. 2021, 113605. [CrossRef] [PubMed] 
127. Rivera, C.; Voipio, J.; Thomas-Crusells, J.; Li, H.; Emri, Z.; Sipila, S.; Payne, J.A.; Minichiello, L.; Saarma, M.; Kaila, K. Mechanism of activity-dependent downregulation of the neuron-specific K-Cl cotransporter KCC2. J. Neurosci. 2004, 24, 4683-4691. [CrossRef] [PubMed]

128. Rivera, C.; Voipio, J.; Kaila, K. Two developmental switches in GABAergic signalling: The $\mathrm{K}^{+}-\mathrm{Cl}^{-}$cotransporter $\mathrm{KCC}^{2}$ and carbonic anhydrase CAVII. J. Physiol. 2005, 562, 27-36. [CrossRef]

129. Ferrini, F.; De Koninck, Y. Microglia control neuronal network excitability via BDNF signalling. Neural Plast. 2013, $2013,429815$. [CrossRef] [PubMed]

130. Glykys, J.; Dzhala, V.; Egawa, K.; Balena, T.; Saponjian, Y.; Kuchibhotla, K.V.; Bacskai, B.J.; Kahle, K.T.; Zeuthen, T.; Staley, K.J. Local impermeant anions establish the neuronal chloride concentration. Science 2014, 343, 670-675. [CrossRef] [PubMed]

131. Ben-Ari, Y.; Khalilov, I.; Kahle, K.T.; Cherubini, E. The GABA excitatory/inhibitory shift in brain maturation and neurological disorders. Neuroscientist 2012, 18, 467-486. [CrossRef]

132. Galtrey, C.M.; Kwok, J.C.; Carulli, D.; Rhodes, K.E.; Fawcett, J.W. Distribution and synthesis of extracellular matrix proteoglycans, hyaluronan, link proteins and tenascin-R in the rat spinal cord. Eur. J. Neurosci. 2008, 27, 1373-1390. [CrossRef]

133. Engesser-Cesar, C.; Ichiyama, R.M.; Nefas, A.L.; Hill, M.A.; Edgerton, V.R.; Cotman, C.W.; Anderson, A.J. Wheel running following spinal cord injury improves locomotor recovery and stimulates serotonergic fiber growth. Eur. J. Neurosci. 2007, 25, 1931-1939. [CrossRef]

134. Fouad, K.; Tetzlaff, W. Rehabilitative training and plasticity following spinal cord injury. Exp. Neurol. 2012, 235, 91-99. [CrossRef]

135. Liu, Z.H.; Yip, P.K.; Priestley, J.V.; Michael-Titus, A.T. A Single Dose of Docosahexaenoic Acid Increases the Functional Recovery Promoted by Rehabilitation after Cervical Spinal Cord Injury in the Rat. J. Neurotrauma 2017, 34, 1766-1777. [CrossRef] [PubMed]

136. Loy, K.; Schmalz, A.; Hoche, T.; Jacobi, A.; Kreutzfeldt, M.; Merkler, D.; Bareyre, F.M. Enhanced Voluntary Exercise Improves Functional Recovery following Spinal Cord Injury by Impacting the Local Neuroglial Injury Response and Supporting the Rewiring of Supraspinal Circuits. J. Neurotrauma 2018, 35, 2904-2915. [CrossRef] [PubMed]

137. Barbeau, H.; Rossignol, S. Initiation and modulation of the locomotor pattern in the adult chronic spinal cat by noradrenergic, serotonergic and dopaminergic drugs. Brain Res. 1991, 546, 250-260. [CrossRef]

138. Feraboli-Lohnherr, D.; Barthe, J.Y.; Orsal, D. Serotonin-induced activation of the network for locomotion in adult spinal rats. J. Neurosci. Res. 1999, 55, 87-98. [CrossRef]

139. Antri, M.; Mouffle, C.; Orsal, D.; Barthe, J.Y. 5-HT1A receptors are involved in short- and long-term processes responsible for 5-HT-induced locomotor function recovery in chronic spinal rat. Eur. J. Neurosci. 2003, 18, 1963-1972. [CrossRef]

140. Leszczynska, A.N.; Majczynski, H.; Wilczynski, G.M.; Slawinska, U.; Cabaj, A.M. Thoracic Hemisection in Rats Results in Initial Recovery Followed by a Late DecreMent. in Locomotor Movements, with Changes in Coordination Correlated with Serotonergic Innervation of the Ventral Horn. PLoS ONE 2015, 10, e0143602. [CrossRef] [PubMed]

141. Saruhashi, Y.; Young, W.; Perkins, R. The recovery of 5-HT immunoreactivity in lumbosacral spinal cord and locomotor function after thoracic hemisection. Exp. Neurol. 1996, 139, 203-213. [CrossRef] [PubMed]

142. Saruhashi, Y.; Matsusue, Y.; Fujimiya, M. The recovery of 5-HT transporter and 5-HT immunoreactivity in injured rat spinal cord. Arch. Orthop. Trauma Surg. 2009, 129, 1279-1285. [CrossRef]

143. Zuchner, M.; Kondratskaya, E.; Sylte, C.B.; Glover, J.C.; Boulland, J.L. Rapid recovery and altered neurochemical dependence of locomotor central pattern generation following lumbar neonatal spinal cord injury. J. Physiol. 2018, 596, 281-303. [CrossRef]

144. Tran, A.P.; Warren, P.M.; Silver, J. The Biology of Regeneration Failure and Success After Spinal Cord Injury. Physiol. Rev. 2018, 98, 881-917. [CrossRef] [PubMed]

145. Beauparlant, J.; van den Brand, R.; Barraud, Q.; Friedli, L.; Musienko, P.; Dietz, V.; Courtine, G. Undirected compensatory plasticity contributes to neuronal dysfunction after severe spinal cord injury. Brain 2013, 136, 3347-3361. [CrossRef] [PubMed]

146. Jiang, Y.Q.; Zaaimi, B.; Martin, J.H. Competition with Primary Sensory Afferents Drives Remodeling of Corticospinal Axons in Mature Spinal Motor Circuits. J. Neurosci. 2016, 36, 193-203. [CrossRef]

147. Torres-Espin, A.; Beaudry, E.; Fenrich, K.; Fouad, K. Rehabilitative Training in Animal Models of Spinal Cord Injury. J. Neurotrauma 2018, 35, 1970-1985. [CrossRef]

148. Sachdeva, R.; Theisen, C.C.; Ninan, V.; Twiss, J.L.; Houle, J.D. Exercise dependent increase in axon regeneration into peripheral nerve grafts by propriospinal but not sensory neurons after spinal cord injury is associated with modulation of regenerationassociated genes. Exp. Neurol. 2016, 276, 72-82. [CrossRef]

149. Tashiro, S.; Nishimura, S.; Iwai, H.; Sugai, K.; Zhang, L.; Shinozaki, M.; Iwanami, A.; Toyama, Y.; Liu, M.; Okano, H.; et al Functional Recovery from Neural. Stem/Progenitor Cell Transplantation Combined with Treadmill Training in Mice with Chronic Spinal Cord Injury. Sci. Rep. 2016, 6, 30898. [CrossRef] [PubMed]

150. Griffin, J.M.; Bradke, F. Therapeutic repair for spinal cord injury: Combinatory approaches to address a multifaceted problem. EMBO Mol. Med. 2020, 12, e11505. [CrossRef]

151. Theisen, C.C.; Sachdeva, R.; Austin, S.; Kulich, D.; Kranz, V.; Houle, J.D. Exercise and Peripheral Nerve Grafts as a Strategy To Promote Regeneration after Acute or Chronic Spinal Cord Injury. J. Neurotrauma 2017, 34, 1909-1914. [CrossRef]

152. Tashiro, S.; Nishimura, S.; Shinozaki, M.; Takano, M.; Konomi, T.; Tsuji, O.; Nagoshi, N.; Toyama, Y.; Liu, M.; Okano, H.; et al. The Amelioration of Pain-Related Behavior in Mice with Chronic Spinal Cord Injury Treated with Neural. Stem/Progenitor Cell Transplantation Combined with Treadmill Training. J. Neurotrauma 2018, 35, 2561-2571. [CrossRef] 
153. Garcia-Alias, G.; Barkhuysen, S.; Buckle, M.; Fawcett, J.W. Chondroitinase ABC treatMent. opens a window of opportunity for task-specific rehabilitation. Nat. Neurosci. 2009, 12, 1145-1151. [CrossRef]

154. Garcia-Alias, G.; Lin, R.; Akrimi, S.F.; Story, D.; Bradbury, E.J.; Fawcett, J.W. Therapeutic time window for the application of chondroitinase ABC after spinal cord injury. Exp. Neurol. 2008, 210, 331-338. [CrossRef]

155. Kubasak, M.D.; Jindrich, D.L.; Zhong, H.; Takeoka, A.; McFarland, K.C.; Munoz-Quiles, C.; Roy, R.R.; Edgerton, V.R.; RamonCueto, A.; Phelps, P.E. OEG implantation and step training enhance hindlimb-stepping ability in adult spinal transected rats. Brain 2008, 131, 264-276. [CrossRef] [PubMed]

156. Munoz-Quiles, C.; Santos-Benito, F.F.; Llamusi, M.B.; Ramon-Cueto, A. Chronic spinal injury repair by olfactory bulb ensheathing glia and feasibility for autologous therapy. J. Neuropathol. Exp. Neurol. 2009, 68, 1294-1308. [CrossRef]

157. Takeoka, A.; Jindrich, D.L.; Munoz-Quiles, C.; Zhong, H.; van den, B.R.; Pham, D.L.; Ziegler, M.D.; Ramon-Cueto, A.; Roy, R.R.; Edgerton, V.R.; et al. Axon regeneration can facilitate or suppress hindlimb function after olfactory ensheathing glia transplantation. J. Neurosci. 2011, 31, 4298-4310. [CrossRef] [PubMed]

158. Lee, Y.S.; Zdunowski, S.; Edgerton, V.R.; Roy, R.R.; Zhong, H.; Hsiao, I.; Lin, V.W. ImproveMent. of gait patterns in step-trained, complete spinal cord-transected rats treated with a peripheral nerve graft and acidic fibroblast growth factor. Exp. Neurol. 2010, 224, 429-437. [CrossRef]

159. van den Brand, R.; Heutschi, J.; Barraud, Q.; DiGiovanna, J.; Bartholdi, K.; Huerlimann, M.; Friedli, L.; Vollenweider, I.; Moraud, E.M.; Duis, S.; et al. Restoring voluntary control of locomotion after paralyzing spinal cord injury. Science 2012, 336, 1182-1185 [CrossRef]

160. Bareyre, F.M.; Kerschensteiner, M.; Raineteau, O.; Mettenleiter, T.C.; Weinmann, O.; Schwab, M.E. The injured spinal cord spontaneously forms a new intraspinal circuit in adult rats. Nat. Neurosci. 2004, 7, 269-277. [CrossRef]

161. Courtine, G.; Song, B.; Roy, R.R.; Zhong, H.; Herrmann, J.E.; Ao, Y.; Qi, J.; Edgerton, V.R.; Sofroniew, M.V. Recovery of supraspinal control of stepping via indirect propriospinal relay connections after spinal cord injury. Nat. Med. 2008, 14, 69-74. [CrossRef]

162. Filli, L.; Engmann, A.K.; Zorner, B.; Weinmann, O.; Moraitis, T.; Gullo, M.; Kasper, H.; Schneider, R.; Schwab, M.E. Bridging the gap: A reticulo-propriospinal detour bypassing an incomplete spinal cord injury. J. Neurosci. 2014, 34, 13399-13410. [CrossRef]

163. Asboth, L.; Friedli, L.; Beauparlant, J.; Martinez-Gonzalez, C.; Anil, S.; Rey, E.; Baud, L.; Pidpruzhnykova, G.; Anderson, M.A.; Shkorbatova, P.; et al. Cortico-reticulo-spinal circuit reorganization enables functional recovery after severe spinal cord contusion. Nat. Neurosci. 2018, 21, 576-588. [CrossRef] [PubMed]

164. Wagner, F.B.; Mignardot, J.B.; Le Goff-Mignardot, C.G.; Demesmaeker, R.; Komi, S.; Capogrosso, M.; Rowald, A.; Seanez, I.; Caban, M.; Pirondini, E.; et al. Targeted neurotechnology restores walking in humans with spinal cord injury. Nature 2018, 563, 65-71. [CrossRef]

165. Fouad, K.; Pedersen, V.; Schwab, M.E.; Brosamle, C. Cervical sprouting of corticospinal fibers after thoracic spinal cord injury accompanies shifts in evoked motor responses. Curr. Biol. 2001, 11, 1766-1770. [CrossRef]

166. Oyinbo, C.A. Secondary injury mechanisms in traumatic spinal cord injury: A nugget of this multiply cascade. Acta Neurobiol. Exp. 2011, 71, 281-299.

167. Pan, J.Z.; Ni, L.; Sodhi, A.; Aguanno, A.; Young, W.; Hart, R.P. Cytokine activity contributes to induction of inflammatory cytokine mRNAs in spinal cord following contusion. J. Neurosci. Res. 2002, 68, 315-322. [CrossRef]

168. Zhang, N.; Yin, Y.; Xu, S.J.; Wu, Y.P.; Chen, W.S. Inflammation \& apoptosis in spinal cord injury. Indian J. Med. Res. 2012, 135, 287-296.

169. Sandrow-Feinberg, H.R.; Izzi, J.; Shumsky, J.S.; Zhukareva, V.; Houle, J.D. Forced exercise as a rehabilitation strategy after unilateral cervical spinal cord contusion injury. J. Neurotrauma 2009, 26, 721-731. [CrossRef]

170. Dugan, E.A.; Jergova, S.; Sagen, J. Mutually beneficial effects of intensive exercise and GABAergic Neural. progenitor cell transplants in reducing neuropathic pain and spinal pathology in rats with spinal cord injury. Exp. Neurol. 2020, 327, 113208. [CrossRef] [PubMed]

171. Alves, E.D.S.; Dos Santos, R.V.T.; de Lira, F.S.; Almeida, A.A.; Edwards, K.; Benvenutti, M.; Tufik, S.; De Mello, M.T. Effects of intensity-matched exercise at different intensities on inflammatory responses in able-bodied and spinal cord injured individuals. J. Spinal Cord Med. 2020, 1-11. [CrossRef] [PubMed]

172. Morland, C.; Andersson, K.A.; Haugen, O.P.; Hadzic, A.; Kleppa, L.; Gille, A.; Rinholm, J.E.; Palibrk, V.; Diget, E.H.; Kennedy, L.H.; et al. Exercise induces cerebral VEGF and angiogenesis via the lactate receptor HCAR1. Nat. Commun. 2017, 8, 15557. [CrossRef]

173. Ying, X.; Xie, Q.; Li, S.; Yu, X.; Zhou, K.; Yue, J.; Chen, X.; Tu, W.; Yang, G.; Jiang, S. Water treadmill training attenuates blood-spinal cord barrier disruption in rats by promoting angiogenesis and inhibiting matrix metalloproteinase-2/9 expression following spinal cord injury. Fluids Barriers CNS 2020, 17, 70. [CrossRef] [PubMed]

174. Zhang, D.; Tang, Q.; Zheng, G.; Wang, C.; Zhou, Y.; Wu, Y.; Xuan, J.; Tian, N.; Wang, X.; Wu, Y.; et al. Metformin ameliorates BSCB disruption by inhibiting neutrophil infiltration and MMP-9 expression but not direct TJ. proteins expression regulation. J. Cell Mol. Med. 2017, 21, 3322-3336. [CrossRef]

175. Noble, L.J.; Donovan, F.; Igarashi, T.; Goussev, S.; Werb, Z. Matrix metalloproteinases limit functional recovery after spinal cord injury by modulation of early vascular events. J. Neurosci. 2002, 22, 7526-7535. [CrossRef]

176. Cohen, M.; Ben-Yehuda, H.; Porat, Z.; Raposo, C.; Gordon, S.; Schwartz, M. Newly ForMed. Endothelial Cells Regulate Myeloid Cell Activity Following Spinal Cord Injury via Expression of CD200 Ligand. J. Neurosci. 2017, 37, 972-985. [CrossRef] 
177. Sun, H.; Li, A.; Hou, T.; Tao, X.; Chen, M.; Wu, C.; Chen, S.; Zhu, L.; Liao, H. Neurogenesis promoted by the CD200/CD200R signaling pathway following treadmill exercise enhances post-stroke functional recovery in rats. Brain Behav. Immun. 2019, 82, 354-371. [CrossRef] [PubMed]

178. Silver, J.; Schwab, M.E.; Popovich, P.G. Central nervous system regenerative failure: Role of oligodendrocytes, astrocytes, and microglia. Cold Spring Harb. Perspect. Biol. 2014, 7, a020602. [CrossRef] [PubMed]

179. Chhaya, S.J.; Quiros-Molina, D.; Tamashiro-Orrego, A.D.; Houle, J.D.; Detloff, M.R. Exercise-Induced Changes to the Macrophage Response in the Dorsal Root Ganglia Prevent Neuropathic Pain after Spinal Cord Injury. J. Neurotrauma 2019, 36, 877-890. [CrossRef]

180. Duan, R.; Qu, M.; Yuan, Y.; Lin, M.; Liu, T.; Huang, W.; Gao, J.; Zhang, M.; Yu, X. Clinical Benefit of Rehabilitation Training in Spinal Cord Injury: A Systematic Review and Meta-Analysis. Spine 2021, 46, E398-E410. [CrossRef]

181. Jones, M.L.; Evans, N.; Tefertiller, C.; Backus, D.; Sweatman, M.; Tansey, K.; Morrison, S. Activity-based therapy for recovery of walking in chronic spinal cord injury: Results from a secondary analysis to determine responsiveness to therapy. Arch. Phys. Med. Rehabil. 2014, 95, 2247-2252. [CrossRef] [PubMed]

182. Gomes-Osman, J.; Cortes, M.; Guest, J.; Pascual-Leone, A. A Systematic Review of Experimental Strategies AiMed. at Improving Motor Function after Acute and Chronic Spinal Cord Injury. J. Neurotrauma 2016, 33, 425-438. [CrossRef]

183. Nacimiento, W.; Sappok, T.; Brook, G.A.; Toth, L.; Schoen, S.W.; Noth, J.; Kreutzberg, G.W. Structural changes of anterior horn neurons and their synaptic input caudal to a low thoracic spinal cord hemisection in the adult rat: A light and electron microscopic study. Acta Neuropathol. 1995, 90, 552-564. [CrossRef] 